\title{
Treatment of the railway freight wagon wash effluents by coagulation methods on accelator reactor
}

\author{
Sławomir Żak ${ }^{1}$ (D) - Terese Rauckyte-Żak ${ }^{1}$ (D) \\ Received: 19 November 2019 / Accepted: 21 June 2021 / Published online: 6 July 2021 \\ (C) The Author(s) 2021
}

\begin{abstract}
This paper presents results of the research carried out on a system made to pretreat the effluents produced in water treatment of dirty surfaces of railway transportation means (RTMs) mainly G, H, T and incidental F classes of rolling stock according to the International Union of Railways (IURs). The installation was designed for coagulation-flocculation pretreatment of wastewater with flow accelator reactor (AR) in total amount of up to $75.0 \mathrm{~m}^{3}$ day ${ }^{-1}$. The raw wastewater (RW) was characterized by a significant diversity of loads: TSS (total suspended solids), TDS (total dissolved solids), COD \& BOD $_{5}$ (chemical \& biochemical oxygen demand) and periodically it had extremely different colors, $\mathrm{T}_{\mathrm{a}}$ (turbidity) and $\mathrm{EE}$ (etheric extract). The application of twostage, coupled acid-alkali or alkaline-acid coagulation using aluminum coagulants with final flocculation and phase separation in the system implemented in practice to treat the wastewater of statistically typical composition, usually allowed to removal, accordingly: EE \& TSS $>99 \%$ and to eliminate completely color and $\mathrm{T}_{\mathrm{a}}$. However, COD and $\mathrm{BOD}_{5}$ were removal at different levels, depending on both initial concentrations and chemical composition of load pools registered in the RW, and a type of coagulation used. The use of pre-oxidation with aqueous solutions of hydrogen peroxide or peracetic acid coupled with coagulation based only on aluminum coagulants helps to achieve equal levels of removal of the basic indicator values and a sanitary clean stream of pretreated wastewater (PW) with a colony forming unit (CFU) of $<100 \mathrm{ml}^{-1}$.
\end{abstract}

Keywords Railway freight wagon wash · Wastewater treatment $\cdot$ Accelator reactor $\cdot$ Two-stage coagulation · Pre-oxidation

\section{Introduction}

RTMs for various cargo types such as: raw materials, semifinished and finished products, participate in transferring huge masses and volumes of goods for use in three basic sectors of each state economy: manufacturing, processing and services, over the target distances [1-7]. This way of mass transportation is most often associated with a permanent change in transported cargos during the time and a significant change in a type and amount of residues on surfaces contaminated by transported goods [8-11]. Intensive use of transport fleets is inseparably connected with the necessity of cleaning dirty wagon surfaces and generation of wastewater loaded with

Sławomir Żak

zak@utp.edu.pl

1 Faculty of Chemical Technology and Engineering, University of Science and Technology, 3 Seminaryjna Street, 85-326 Bydgoszcz, Poland the composition of pollutants as a function of the characteristics of transported materials [12-20]. An optimal organizational solution is a group cleaning of the transport fleet in a form of collective wagon washes to eliminate dispersed sources of wastewater and other wastes from the ones generated in the processes of wagon cleaning [21-28]. The character of washing facility operation must firstly take into account a class of rolling stock according to the division adopted by the IURs [29]. In case of wash facilities covering railway freight wagons of classes E, F, G, H, K, L, R and T, with the exception of rolling stock of classes I, $\mathrm{Z}$ and $\mathrm{U}$, water washes not requiring special treatment conditions may be used. Then, the generated wastewater will mostly be characterized by significant differences in composition and concentration of TSS, $\mathrm{T}_{\mathrm{a}}$, mainly caused by the presence of colloidal systems, the content of the sum of soluble mineral and/or organic substances TDS, as well as TC (total conductivity). $\mathrm{COD} \& \mathrm{BOD}_{5}$ and occasional color, as well as traces of oil, fat and/or oil derivatives included in the FOG (fats, oils \& grease) index [8-11, 19-23] are also of less significance. Values of these parameters depend on the physical state, chemical 
composition, fragmentation, moisture content, heterophasic scale, packaging methods and tightness of packaging, as well as long-term repeatability of the category of transported materials $[9,11]$. The composition and level of contamination load in the wastewater may also be a result of incidental mechanical damage to packaging that secures the materials during transport operations [11]. The total loads of contaminants disposed to the cleaning installations also include incidental microbiological and/or mycological infections, and parasitological infections, which in extreme cases, force the necessity of using periodical disinfection of the washed dirty surfaces of the rolling stock [30-33].

In literature, you can find mainly the records of methods of physicochemical pretreatment of the wastewater from such processes which consist in the application of coagulationflocculation $[34,35]$ and electrocoagulation systems $[36$, 37]. Available process data and knowledge of physicochemical and/or biological basis of pretreatment and/or purification methods are quite limited.

The purpose of this work was to select a system to treat wastewater generated by water-based washing of railway rolling stock of $\mathrm{G}, \mathrm{H}, \mathrm{T}$ and incidentally $\mathrm{F}$ class on the designed and built installation, based on coagulation.

\section{Materials and methods}

\section{Raw wastewaters}

Generated RW was mostly a multiple, water-based dilution of component residues of transported freight masses (mainly G, $\mathrm{H}$ and $\mathrm{T}$ categories with incidental $\mathrm{F}$ category cases), characterized by significant changes in composition (Table 1) and load size. The pollution pool mainly consisted of unstable colloidal- and suspended polydisperse systems with a tendency to fast sedimentation, often with reduction properties (mostly a permanent decrease in $\mathrm{rH}$ (redox potential) value of wastewater kept during the time $-8-27 \mathrm{mV} \mathrm{day}^{-1}$ on average) with a tendency of rotting and coloring, which forced the necessity of their pretreatment.

\section{Experimental installation}

The installation of a physicochemical treatment plant (PTP) with a daily capacity of up to $75.0 \mathrm{~m}^{3}$, in which the experiment was carried out, is presented in a simplified scheme in Fig. 1 [38]. RW from cleaning the transport surfaces of rolling stock, flowed gravitationally into a retention-average tank (1) and it was outflowed to its equalization and sedimentary section (1.1), where the composition was averaged and pollutants were separated in a water flux in a form of easily settling suspensions and randomly floating, insignificant volumes of light liquids (e.g. FOG). Then, they flowed through an overfall system to a pumping part (1.2) where a processing pump (1.3) pumped the processed wastewater to a pipe reactor $(2)\left(\mathrm{RW}_{(\mathrm{s})}\right.$ marked flux). Under turbulent flow conditions, coagulant $\mathrm{I}^{\mathrm{O}}$ from tank (9) and/or the coagulant II $^{\mathrm{O}}$ or neutralizing reagent (from tank 10) were dosed with dosing pumps (9.1) and (10.1) respectively, depending on the adopted option of one- or twostage coagulation. The pipe reactor (2) equipped with process $\mathrm{pH}-$-meters at its inlet $(\mathrm{pH} 1)$ and outlet $(\mathrm{pH} 2)$, provided fast mixing and uniform distribution of chemical reagents before wastewater entering the processing volumes of a central, twochamber reactor (3) of AR class. Before being injected into a fast mixing chamber (3.1) equipped with a slow-running frame mixer (3.2), $0.3 \%$ flocculent water solution was metered by a pump (11.1) from a preparation and dosing station (11). Then, the wastewater with formed flakes flowed through a deflector transfer system into the sedimentary chamber (3.3) of the AR, where, under the influence of gravitational forces, sedimentary separation and thickening of flocculated dispersed contaminant particles took place in the sedimentary pockets. During the next stage, the stream from the overflow system was directed to the process unit of an open, multilayer gravity filter (4), on which the residual colloidal and suspended fractions entrained by the water stream were stopped. PW as a filtrate was stored in a retention tank (5), from where it was fed by a pump set (5.2) to be reused in the cycle of cleaning the dirty surfaces of railway transport rolling stock (after being topped up with potable water (TW)) or discharged into the municipal sewer system. The developed installation also included the ability to disinfect wagons' dirty surfaces by final washing with TW stored in tank (6) and pumped with pump set (6.1), after which, it was downstreamed with a water solution of peracetic acid or hydrogen peroxide, optionally metered into the pipeline in an appropriate proportion by a pump (12.2) from the station' tank (12). There was also an option of disinfecting the gravel bed of filter (4) during back flushing with water from tank (5), additionally supplied with disinfectant pumped by pump (12.1) from the station tank (12). The wagon wash operation control software also included the option of pre-disinfection of the dirty surfaces of freight wagons before the physicochemical pretreatment stage, which was also tested in the PTP. The whole process system was equipped with a water supply unit (TW) in order to cover the losses caused by evaporation, the water remaining on the washed rolling stock surfaces; etc. (ca. $10 \%$ per batch of whole pre-cleaning cycle). In order to avoid excessive salinity of PW periodically, every $3-5$ batches, the entire volume of used cleaning water was discharged into the sewer system. This volume was estimated on the basis of conductivity measurements - a limit value was established at the level of $2.5 \mathrm{mS} / \mathrm{cm}$ as salt discolorations often remained on dried surfaces for higher salt concentrations. In the treatment process of wastewater from railway rolling stock water cleaning, the waste flows were also generated in a form of: 
Table 1 Characteristic of raw wastewaters (RW) and after detention and sedimentation $\left(\mathrm{RW}_{(\mathrm{S})}\right)$

\begin{tabular}{|c|c|c|c|}
\hline No. & Parameter, unit & Range value for RW (median's) ${ }^{\text {a) }}$ & Range value for $\mathrm{RW}_{(\mathrm{s})}$, (median's) ${ }^{\mathrm{a}, \mathrm{b})}$ \\
\hline 1 & $\mathrm{pH}$ & $6.4-8.8(7.4)$ & $6.2-8.2(7.2)$ \\
\hline 2 & Color (mgPt.Co ${ }^{-1}$ ) & $12-41(27)$ & $11-28(18)$ \\
\hline 3 & TDS (mg $\left.\mathrm{l}^{-1}\right)$ & $286.4-1004.0(462.4)$ & $216.9-885.9(437.8)$ \\
\hline 4 & $\operatorname{TSS}\left(\mathrm{mg} \mathrm{l}^{-1}\right)$ & $263.2-1577.3(948.9) 4011.6^{c)}$ & $89.6-211.2(140.8)$ \\
\hline 5 & $\mathrm{COD}\left(\mathrm{mg} \mathrm{l}^{-1}\right)$ & $293.3-1307.0(424.5)$ & $243.6-1004.9(381.4)$ \\
\hline 6 & $\mathrm{BOD}_{5}\left(\mathrm{mg} \mathrm{l}^{-1}\right)$ & $40.7-255.0(148.1)$ & $34.8-209.3(103.3)$ \\
\hline 7 & $\mathrm{EE}\left(\mathrm{mg}^{-1}\right)$ & $0.82-26.44(10.26)$ & $0.04-2.41(0.72)$ \\
\hline 8 & $\mathrm{TN}\left(\mathrm{mg} \mathrm{l}^{-1}\right)$ & $0.95-22.16(4.60)$ & $0.28-13.17(3.39)$ \\
\hline 9 & $\mathrm{AN}\left(\mathrm{mg} \mathrm{l}^{-1}\right)$ & $0.11-10.27(3.66)$ & $<0.10-9.41(2.95)$ \\
\hline 10 & $\mathrm{TP}\left(\mathrm{mg} \mathrm{l}^{-1}\right)$ & $0.24-5.01(2.63)$ & $0.19-4.73(1.56)$ \\
\hline 11 & HMs, $\left.\left(\mathrm{mg} \mathrm{l}^{-1}\right)^{\mathrm{d}}\right)$ & $0.23-4.66(3.09) 7.64^{\mathrm{e} 1)}$ & $<0.10-2.74(1.92) 4.13^{\mathrm{e} 2)}$ \\
\hline
\end{tabular}

where:

a) the median $\left(\mathrm{m}_{1 / 2}\right)$ was determined basing on 187 measurement series over a six-month period for samples of RW taken at point A (Fig. 1) and for samples $\mathrm{RW}_{(\mathrm{s})}$ taken at point B (Fig. 1) after the retention in storageaveraging tank (1) and sedimentation;

b) the listed analysis results include cases where retention time of RW in section (1.1) of storage average tank (1) was determined as at least $90.0 \pm 5.0 \mathrm{~min}$ and was not pumped into section (1.1) from intermediate tank (8) of the filtrate generated on filter unit (7) or a mixture of filtrate and water streams generated by backflushing the gravel filter water bed (4) (Fig. 1);

c) a single case of the wastewater generated from wagon washing after the transport of crushed rock aggregate;

d) the parameter heavy metals $(\mathrm{HMs})$ includes the volumetric determination of the following elements: $\mathrm{Cd}, \mathrm{Cr}_{(\mathrm{T})}$, $\mathrm{Cu}, \mathrm{Hg}, \mathrm{Mn}, \mathrm{Ni}, \mathrm{Pb}$ and $\mathrm{Zn}$ (no $\mathrm{Cd}, \mathrm{Cr}_{(\mathrm{T})}$ were found) and $\mathrm{Hg}$ were found in any of the analyzed samples at levels exceeding the concentration threshold of $0.1 \mathrm{mg} \mathrm{l}^{-1}$ );

${ }^{\mathrm{e} 1}$ and e2) for this incidental value of determined HMs, the presence of the following individual metals (in $\mathrm{mg}^{-1}$ ) was found in the stream of ${ }^{\mathrm{e} 1)} \mathrm{RW}:(\mathrm{Zn}) 3.70,(\mathrm{~Pb}) 2.19$, (Mn) 0.62 and $(\mathrm{Cu}) 1.33$, and for the ${ }^{\mathrm{e} 2)} \mathrm{RW}_{(\mathrm{s})}$ : $(\mathrm{Zn}) 2.37$, $(\mathrm{Pb}) 1.06$, $(\mathrm{Mn}) 0.56$ and $(\mathrm{Cu}) 0.14$, whereas the others (i.e., $\mathrm{Cd}, \mathrm{Cr}_{(\mathrm{T})}, \mathrm{Cu}, \mathrm{Hg}$ and $\mathrm{Ni}$ ) did not exceed concentration levels of $0.1 \mathrm{mg}^{-1}$ a) sediments accumulated in the sedimentation section (1.1) of the retention-average tank (1) - periodically removed (1-2 times a week) from the tank;

b) sediments accumulated in the slow mixing chamber, in its sedimentary pockets of the sedimentary zone (3.3) of AR, which were periodically pumped by the sludge pump (3.4) into a dewatering unit, in a form of open gravity bag filters (7), where suspended solids were thickened using gravity forced filtration (the dewatered sediment was periodically removed), whereas a filtrate was directed to the start of the treatment system through an intermediate tank (7.1) and a pumping station (8);

c) backflushing waters from the gravel filter backflushing process (4) - with a stream of pretreated water from tank (5) delivered by a pump (5.1) (the water backflushing of the filter was preceded by a purge of compressed air pumped by a blower (4.1). The used backflushing waters from the pumping station (8) were directed to the tank (1) at the beginning of the system with a pump (8.1). As an option with the gravel bed disinfection, the backflushing waters pumped from the tank (5) were additionally treated with water solutions of $\mathrm{CH}_{3} \mathrm{COOOH}$ or $\mathrm{H}_{2} \mathrm{O}_{2}$ metered with a pump (12.1) from station tank (12).

\section{Process reagents}

Commercial coagulants of Kemira Kemipol were used for the research [39] for categories $\left(\mathrm{I}^{\circ}\right)$ and/or $\left(\mathrm{II}^{\circ}\right)$ of PIX®, PAX® and $\mathrm{SAX}{ }^{\circledR}$ classes, the basic characteristics of which are given in Table 2.

The laboratory scale results were corrected and compared on a full scale installation using the algorithm of the control program for such doses of the tested coagulants that enabled us to obtain final $\mathrm{pH}<9.0$ and to use the same doses of flocculent $\left(0.3 \%\right.$ aqueous solution FLOPAM ${ }^{\mathrm{TM}}$ FO 4800 SNF Floerger) for all the tested coagulation variants (also using preliminary disinfection with aqueous solution $1.5 \%$ $\mathrm{CH}_{3} \mathrm{COOOH}$ (prepared from $15 \%\left(\rho=1.1610 \mathrm{~g} \mathrm{ml}^{-1}\right)$ (ENVOLAB fine chemicals)) or $1.0 \% \mathrm{H}_{2} \mathrm{O}_{2}$ (prepared from $30 \%\left(\rho=1.1110 \mathrm{~g} \mathrm{ml}^{-1}\right)$ (ENVOLAB fine chemicals)). The established final $\mathrm{pH}$ value resulted from differences in the initial pHs of commercial coagulants and the concentrations of coagulant metal (Al(III) for PAX® group coagulants (16, 18 ) and Fe(III) for PIX® group coagulants (113, 116 and 122)) compensated by optimal volumetric doses of different initial $\mathrm{pH}$, dosed into the pipe reactor (2). For the programmed final $\mathrm{pH}$ level of $8.0 \pm 0.3$, the maximum removal of indicator 


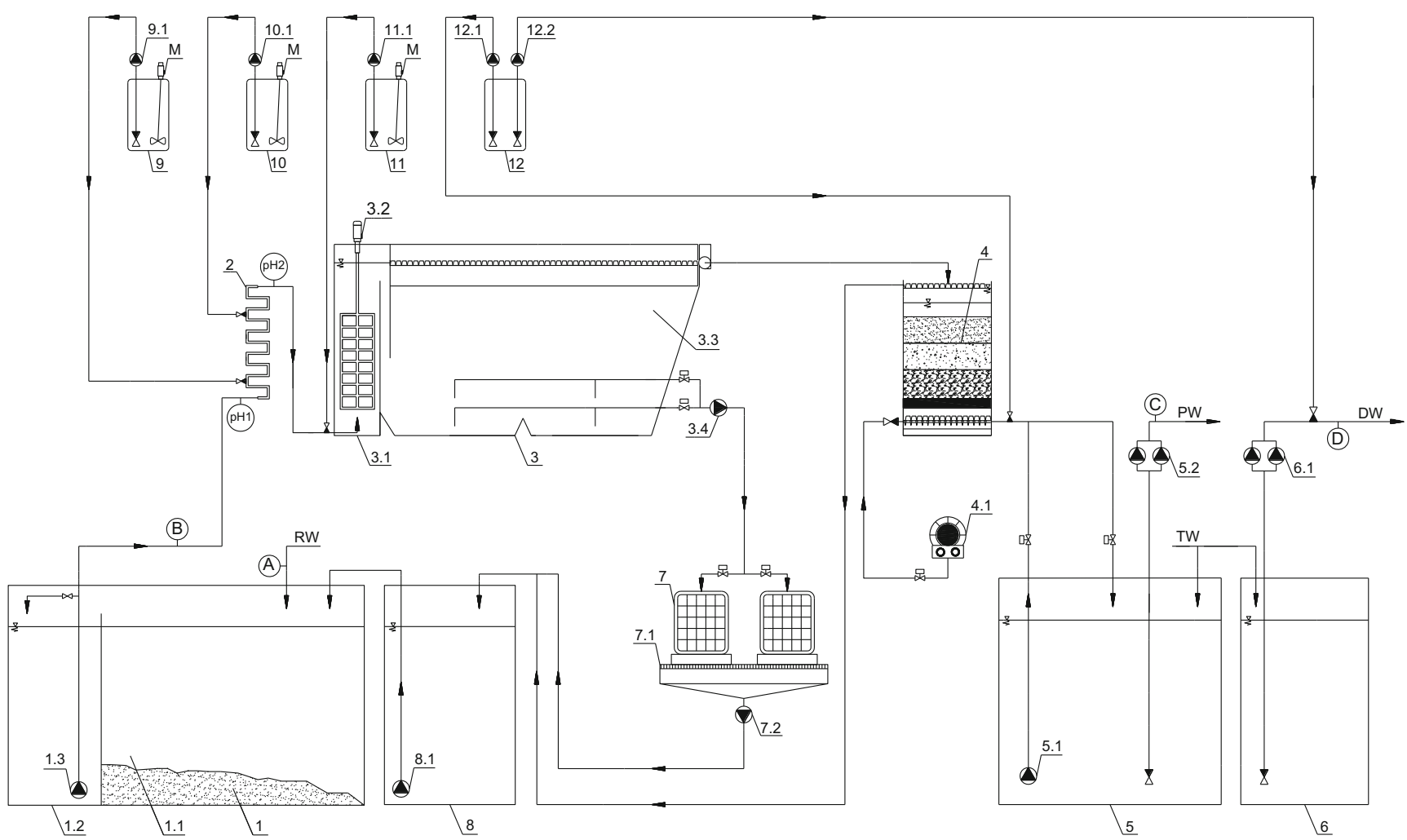

Fig. 1 Simplified process flowchart of PTP; where: 1) retention-average tank for RW, 1.1) sedimentation section, 1.2) pump section, 1.3) process pump and bypass, 2) pipe reactor, 3) central process reactor of AR type, 3.1) quick mixing chamber, 3.2) slow frame mixer, 3.3) slow mixing chamber and sedimentary chamber with sedimentary pockets, 3.4) sedimentary pump, 4) open multi-layer gravel filter, 4.1) blower, 5) retention tank for PW, 5.1) bypass pump for averaging the composition of the pretreated stream and for backflushing the gravel filter (4), 5.2) pretreated water stream pump set for washing wagons or for discharging into the sewer system, 6) potable TW tank, 6.1) potable TW pump set, 7) gravity sludge dewatering station, 7.1) intermediate filtrate tank, 7.2)

values was obtained at comparable concentrations of the introduced metal (M) of the tested commercial coagulant.

\section{Corrected by calculation volume}

In order to compare the efficiency, the above mentioned concentration differences were eliminated by introducing the corrected by calculation volume $\left(\mathrm{V}_{\mathrm{r}}\right)$ per unit $1.0 \mathrm{~m}^{3}$ of treated wastewater according to the following relationships (a) and (b):

$$
\begin{aligned}
& \mathrm{V}_{\mathrm{r}}=\mathrm{V}_{\text {exit }}-\mathrm{V}_{\text {out }}, \\
& \mathrm{V}_{\text {out }}=\mathrm{V}_{\mathrm{c}}+\mathrm{V}_{\mathrm{n}}+\mathrm{V}_{\mathrm{f}}+\mathrm{V}_{\text {ox }}
\end{aligned}
$$

where:

$\mathrm{V}_{\text {exit }}$ - total volume at the system outlet $\left(\mathrm{m}^{3}\right), \mathrm{V}_{\text {out }}-$ sum of external volumes discharged into the treated wastewater $\left(\mathrm{m}^{3}\right)$, including $\mathrm{V}_{\mathrm{c}}$ - unit volume of coagulant solution (in two-stage coagulation options $\mathrm{V}_{\mathrm{c}}=\mathrm{V}_{\mathrm{c}(\mathrm{I})}+\mathrm{V}_{\mathrm{c}(\mathrm{II})}$, where: $\mathrm{V}_{\mathrm{c}(\mathrm{I})}-$ filtrate pump, 8) pumping station of wastewater from backflushing process of gravel filter (4) and of filtrate from sludge dewatering node (7), 8.1) pump of mixture of filter backflushing water and filtrate, 9) dosing station of coagulant $\left.\left(\mathrm{I}^{\circ}\right), 9.1\right)$ coagulant $\left(\mathrm{I}^{\circ}\right)$ dosing pump, 10) dosing station for dosing coagulant $\left(\mathrm{II}^{\mathrm{O}}\right)$ or neutralization reagent, 10.1) dosing pump of coagulant $\left(\mathrm{II}^{\circ}\right)$ or neutralization reagent, 11) flocculent solution preparation and dosing station, 11.1) flocculent dosing pump, 12) disinfectant dosing station, 12.1 and 12.2) disinfectant dosing pumps, DW - disinfectant water, A, B and C-sampling points for the analyses of $\mathrm{RW}, \mathrm{RW}_{(\mathrm{s})}$ and $\mathrm{PW}, \mathrm{D}-\mathrm{DW}$ sampling point for control analyses, $\mathrm{pH} 1$ and $\mathrm{pH} 2$ - process $\mathrm{pH}$-meters at the inlet and outlet of pipe reactor (2)

volume of coagulant $\left(\mathrm{I}^{\mathrm{O}}\right)$, and $\mathrm{V}_{\mathrm{c}(\mathrm{II})}$ - volume of coagulant $\left.\left(\mathrm{II}^{\mathrm{O}}\right)\right)\left(\mathrm{m}^{3}\right), \mathrm{V}_{\mathrm{n}}-$ unit volume of $7.5 \%$ aqueous $\mathrm{NaOH}$ solution for correction of reaction to final level within $\mathrm{pH}=8.0 \pm 0.3$ (only in the option of single-stage coagulation with acidic coagulants) $\left(\mathrm{m}^{3}\right), \mathrm{V}_{\mathrm{f}}$ - unit volume of $0.3 \%$ aqueous flocculent solution $\left(\mathrm{m}^{3}\right)$ and $\mathrm{V}_{\mathrm{ox}}$ - unit volume to be considered in the options with disinfection using aqueous solutions of $\mathrm{CH}_{3} \mathrm{COOOH}$ or $\mathrm{H}_{2} \mathrm{O}_{2}\left(\mathrm{~m}^{3}\right)$.

The volume correction did not take into account the dilution effect of the filtrate generated on the filter unit (7) or the mixture of the filtrate streams and the streams generated by backflushing the gravel bed of the filter (4), as the tests were not performed under such conditions - no wastewater from the intermediate tank was pumped during the tests (8).

\section{Analytical part}

In the collected, averaged samples of RW (point A in Fig. 1), after storage for sedimentation $\left(\mathrm{RW}_{(\mathrm{s})}\right)$ in section $(1.1)$ of the 
Table 2 Basic characteristics of commercial aluminum and iron coagulants used for the research [39]

\begin{tabular}{|c|c|c|c|c|}
\hline No. & Coagulant (basic composition) & $\begin{array}{l}\text { Reaction, } \\
\mathrm{pH}\end{array}$ & $\begin{array}{l}\text { Density, } \mathrm{g} \\
1^{-1} \text { at } 20^{\circ} \mathrm{C}\end{array}$ & $\begin{array}{l}\text { Metal } \\
\text { content }^{\text {a) }}, \%\end{array}$ \\
\hline 1 & $\begin{array}{l}\mathrm{PIX} \circledast 113 \\
\left(\mathrm{Fe}_{2}\left(\mathrm{SO}_{4}\right)_{3} \text { in aqueous solution } \mathrm{H}_{2} \mathrm{SO}_{4}\right)\end{array}$ & $<1$ & $1500-1570$ & $11.0 \pm 0.4$ \\
\hline 2 & $\begin{array}{l}\mathrm{PIX}{ }^{\circledR} 116 \\
\left(\mathrm{FeCl}_{3} \text { in aqueous solution } \mathrm{HCl}\right)\end{array}$ & $<1$ & $1310-1390$ & $11.5 \pm 0.5$ \\
\hline 3 & $\begin{array}{l}\text { PIX® } 122 \\
\left(\mathrm{Fe}_{2}\left(\mathrm{SO}_{4}\right)_{3} \text { in aqueous solution } \mathrm{H}_{2} \mathrm{SO}_{4}\right)^{\text {b) }}\end{array}$ & $<1$ & $1550-1570$ & $12.6 \pm 0.3$ \\
\hline 4 & $\begin{array}{l}\mathrm{PAX} \otimes 16 \\
\left(\mathrm{AlCl}_{3} \text { and polyaluminum chloride }\left(\mathrm{Al}(\mathrm{OH})_{\mathrm{r}} \mathrm{Cl}_{\mathrm{s}}+\mathrm{H}_{2} \mathrm{O}(\mathrm{r}+\mathrm{s}\right.\right. \\
\quad=3 \text { where: } 1.05<\mathrm{r}<2) \text { in aqueous solution } \mathrm{HCl})^{\mathrm{c})}\end{array}$ & $<1$ & $1250-1280$ & $\begin{array}{l}8.2 \pm 0.2 \\
\left(\mathrm{Al}_{2} \mathrm{O}_{3}-15.5\right. \\
\quad \pm 0.4)\end{array}$ \\
\hline 5 & $\begin{array}{l}\text { PAX® } 18 \\
\left(\mathrm{AlCl}_{3} \text { and polyaluminum chloride }\left(\mathrm{Al}(\mathrm{OH})_{\mathrm{r}} \mathrm{Cl}_{\mathrm{s}}+\mathrm{H}_{2} \mathrm{O},(\mathrm{r}+\mathrm{s}\right.\right. \\
\quad=3 \text { where: } 1.05<\mathrm{r}<2) \text { in aqueous solution } \mathrm{HCl})\end{array}$ & $1.0 \pm 0.2$ & $1350-1370$ & $\begin{array}{l}9.0 \pm 0.3 \\
\left(\mathrm{Al}_{2} \mathrm{O}_{3}-17.0\right. \\
\quad \pm 0.6)\end{array}$ \\
\hline 6 & $\begin{array}{l}\mathrm{SAX} \circledast 18 \\
\left(\mathrm{Na}_{2} \mathrm{Al}_{2} \mathrm{O}_{4} \text { in aqueous solution } \mathrm{NaOH}\right)\end{array}$ & $12.5 \pm 0.5$ & $1390-1510$ & $\begin{array}{l}9.5 \pm 0.5 \\
\left(\mathrm{Al}_{2} \mathrm{O}_{3}-18.0\right. \\
\quad \pm 1.0)^{\mathrm{e})}\end{array}$ \\
\hline
\end{tabular}

where:

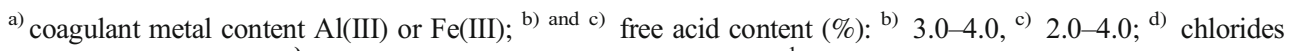
content (\%): 21.0 $\pm 2.0,{ }^{\mathrm{e})} \mathrm{Na}_{2} \mathrm{O} / \mathrm{Al}_{2} \mathrm{O}_{3}$-based - 1.65-1.75 $\mathrm{mol} \mathrm{mol}^{-1}$ tank (1) (point B in Fig. 1) and at the outlet from the plant (PW) (point C in Fig. 1).

\section{Physicochemical parameters}

In accordance with the applications given in the standards for water and wastewater, the following indicative values were determined (according to Polish Standards [40], APHA, AWWA and WEF [41]). The presence and concentrations of HMs such as $\mathrm{Cd}, \mathrm{Cr}_{(\mathrm{T})}, \mathrm{Cu}, \mathrm{Ni}, \mathrm{Mn}, \mathrm{Pb}$ and $\mathrm{Zn}$ were also checked and determined by FAAS method according to PNISO 8288:2002 and $\mathrm{Hg}$ method using cold vapour technique according to PN-EN 12338:2001 on AAS 700 Perkin Elmer apparatus (mineralization $\mathrm{H}_{2} \mathrm{SO}_{4}\left(\rho=1.8420 \mathrm{~g} \mathrm{ml}^{-1}\right)-$ $\mathrm{HClO}_{4}\left(\rho=1.6510 \mathrm{~g} \mathrm{ml}^{-1}\right)$ in $6: 4$ volume proportion). Hydrogen peroxide (iodometric method [42]) or peracetic acid (method described in positions [43, 44] and QUANTOFIX® Peracetic acid 500 and 2000 (Macherey-Nagel GmbH \& Co. $\mathrm{KG}$ )) were determined in averaged samples of DW (point D on Fig. 1) from an autonomous process node. When the option of pre-disinfection with oxidants in the form of aqueous solutions of $\mathrm{CH}_{3} \mathrm{COOOH}$ or $\mathrm{H}_{2} \mathrm{O}_{2}$ was applied, the COD determination was corrected. Actual chemical oxygen demand was given after correction of this value by subtracting the share of residual hydrogen peroxide (from peracetic acid it is released according to simplified reaction scheme): $2 \mathrm{CH}_{3} \mathrm{COOOH}+$ $2 \mathrm{H}^{+} \rightarrow 2 \mathrm{CH}_{3} \mathrm{COOH}+\mathrm{H}_{2} \mathrm{O}_{2}$ [45] on the basis of $\mathrm{COD}_{\omega}=$ $\mathrm{COD}_{v}-\varphi \Psi\left(\mathrm{COD}_{\omega}-\right.$ actual, $\mathrm{COD}_{v}-$ determined in the post-reaction test, $\Psi-\mathrm{H}_{2} \mathrm{O}_{2}$ concentration in the test was determined by iodometric method [42], $\varphi=0.25$ - correction coefficient adopted on the basis of data from the position [45-49]).

\section{Biological parameters}

Periodical control tests were also applied for the general loading of RW and PW streams in accordance with the methodologies for the total number of microorganisms in $22 \pm 2{ }^{\circ} \mathrm{C}$ after $72 \mathrm{~h}$ and in $36 \pm 2{ }^{\circ} \mathrm{C}$ after $48 \mathrm{~h}$ according to PN-EN ISO 6222:2004, determining the level of CFU ml ${ }^{-1}$ parameter. A bacterial colony counter (LKNBTR-CHE-025 ADVERTI) was used for quantitative determinations. Moreover, in order to detect and identify bacteria that may appear in the tested samples of RW and/or PW, the following system analyses were used in the determinations: 1) Clostridium titre (incubation at $37^{\circ} \mathrm{C}$ for $24-48 \mathrm{~h}$ in Thiogllycollate Broth at $37^{\circ} \mathrm{C}$ ). The presence of Clostridium perfringens was determined by screening on TSN Agar - incubation at $46{ }^{\circ} \mathrm{C}$ for $24 \mathrm{~h}$ under anaerobic conditions, 2) Salmonella and Shigella (preincubation at $37{ }^{\circ} \mathrm{C}$ for $18 \mathrm{~h}$ in Buffered Water), 2a) screening on Tetrathionate Broth - incubation at $43{ }^{\circ} \mathrm{C}$ for $24 \mathrm{~h}, 2 \mathrm{~b})$ screening on Selenite Broth - incubation at $37^{\circ} \mathrm{C}$ for 18-20 h, 3) Salmonella sp. (screening for BPLS Agar) incubation at $37^{\circ} \mathrm{C}$ for $24 \mathrm{~h}, 3$ a) SS Agar - incubation at $37^{\circ} \mathrm{C}$ for $24 \mathrm{~h}, 3 \mathrm{~b}$ ) Bismuth Sulf. Agar - incubation at $37^{\circ} \mathrm{C}$ for 24 h, 3c) Pril Mannitol Agar - incubation at $37^{\circ} \mathrm{C}$ for $24 \mathrm{~h}$, medium: sodium and acid tetrationate with sodium selenite, discriminating-selective SS and Soltys - incubation at 37 and $43{ }^{\circ} \mathrm{C}, 3 \mathrm{~d}$ ) Shigella sp. (screening for SS Agar) - incubation at $37^{\circ} \mathrm{C}$ for $24 \mathrm{~h}$, XLC Agar - incubation at $37^{\circ} \mathrm{C}$ for $24 \mathrm{~h}$, 
Bismuth Sulf. Agar - incubation at $37{ }^{\circ} \mathrm{C}$ for $24 \mathrm{~h}$, Pril Mannitol Agar - incubation at $37^{\circ} \mathrm{C}$ for 24 h. Salmonella and Shigella were also identified by API 20 E (for Enterobacteriaceae). Detailed literature used for the development of the methodologies is given in [50-57]. Periodic parasitological evaluation was performed by means of microscopic analysis with the use of Delta Optical Genetic PRO Trino 40-1000x (4014066607) with 1600x option and Bresser MicroCam electronic eyepiece with a resolution of 5.0 million Pixels (maximum resolution $2592 \times 1944$ Pixels) and the application of basic calibration (measurement) slides with $1 / 10 \mathrm{~mm}$ micrometric graduation (Bresser). The presence of live intestinal parasite eggs Ascarius sp., Trichuris sp. and Toxocara $s p$. in the examined sample volumes was determined (after its initial concentration, flotation and centrifugation) by microscopic method using the indications given in $[58,59]$.

\section{Results and discussion}

\section{One-stage coagulation}

At the preliminary stage of this research [60], coagulation methods were selected, with the indication of double-stage coagulation to pretreat the tested wastewater. This approach was introduced by the results obtained in laboratory scale, proving unequivocally that the use of one-stage coagulation with acidic aluminum or iron coagulants with $\mathrm{pH}$ correction using 5.0 or $7.5 \%$ aqueous $\mathrm{NaOH}$ solution or $5.0 \%$ aqueous $\mathrm{Ca}(\mathrm{OH})_{2}$ solution does not allow us to obtain repeatability of levels of removal regarding basic indicator parameters within satisfactory limits for statistically typical loads of RW. The values of random distribution at the level of $\pm 50 \%$ with reference to the value of median $\mathrm{m}_{1 / 2}$ determined for indicators in wastewater streams $\left(\mathrm{PW}_{(\mathrm{s})}\right)$ were assumed in a standard way. The application of such systems in practice did not allow stable operation of the system measured by the efficiency and repeatability of the removal of contaminants. For example, the application of one-stage coagulation in the installation as the simplest variant with the use of iron coagulant PIX ${ }^{\circledR}$ 113 (acid solution $\mathrm{Fe}_{2}\left(\mathrm{SO}_{4}\right)_{3}$ ) and neutralization with $7.5 \%$ aqueous $\mathrm{NaOH}$ solution led in statistically typical cases to the reduction of both TSS \& EE $>99 \%$. However, it was possible only owing to the use of multilayer gravel filter (4) (Fig. 1). On the other hand, the removal of COD (48-67\%), $\mathrm{BOD}_{5}(34-51 \%)$ (Table 3) was at different levels. For TDS, it was difficult to find an unambiguous and repeatable level of the removal of this parameter. Besides, the application of coagulation system (k) with neutralization (n) to correct the reaction $(\mathrm{pH})$ resulted in an additional pool of measurable secondary external salinity $\left(\operatorname{TDS}_{(\mathrm{k})(\mathrm{n})}\right)$ coming from the dosed purifying reagents. Moreover, for full scale tests on $\mathrm{PW}_{(\mathrm{s})}$ stream, the pretreatment option based on the constant dose of coagulant and neutralizing reagent, a color problem at the outflow often occurred, which was caused by the excess of $\mathrm{Fe}(\mathrm{III})$-aquacomplexes in the pretreated water [61, 62]. The periodical excess of $\mathrm{Fe}(\mathrm{III})$ in relation to optimal doses and its coordination properties, which resulted in the generation of colored bonds from lemon yellow ((e.g. caused by the presence of chlorides $\left(\left[\mathrm{Fe}(\mathrm{Cl})_{\alpha}\right]^{(\alpha-3)}\right.$ especially after the use of coagulant PIX® $\left.{ }^{\circledR} 116\right)$ and $\left(\left[\mathrm{Fe}\left(\mathrm{H}_{2} \mathrm{O}\right)_{\beta}\right]^{3+}\right)$ through yellow caused by the presence of sulphates $\left[\mathrm{Fe}\left(\mathrm{SO}_{4}\right) \gamma\right]^{(-2 \gamma+3)}$ to red (e.g. caused by the presence of acetates $\left[\mathrm{Fe}\left(\mathrm{CH}_{3} \mathrm{COO}\right)_{2}\right]^{+}$when peracetic acid was used, in the predisinfection option, where: $\alpha, \beta, \gamma-$ number of chloride, hydroxo or sulphate ligands respectively) [63-67]. In such a variant of coagulation treatment of stream $\mathrm{RW}_{(\mathrm{s})}$, it was necessary to overdose the acid coagulant (k) and to increase appropriately the dosage of neutralizing reagent (n) in order to ensure a certain repeatability of the removal levels of indicator values. It is inseparably connected with the increase in generated post-process sludge volume and the increase in secondary salinity $\left(\operatorname{TDS}_{(\mathrm{k})(\mathrm{n})}\right)$ originating from dissociation and hydrolysis of soluble coagulant salt $(\mathrm{k})$ and hydroxide - as a neutralizing reagent $(\mathrm{n})$. In this process option, the external secondary salinity $\left(\operatorname{TDS}_{(\mathrm{k})(\mathrm{n})}\right)$ may not be quantitatively compensated by sorption occurring on the precipitated floccules of dispersed contaminants and colloidal products of coagulant metal hydrolysis [68]. On the other hand, it may be compensated by the effect of dilution with supplementary water (ca. $10 \%$ of the process volume for a single batch of a complete treatment cycle). Such solution is a simple way to eliminate only dispersed pollutants (dispersion) in the aqueous phase, without any significant removal of pools of dissolved particle charges with an additional generation of secondary cationic-anionic salinity $\left(\operatorname{TDS}_{(\mathrm{k})(\mathrm{n})}\right)$. Comparative studies to check if there are significant differences in the efficiency of PIX® 113, PIX® 116 and PIX® 122 coagulants showed that the differences in the removal levels of such parameters as COD, $\mathrm{BOD}_{5}, \mathrm{TN}, \mathrm{AN} \& \mathrm{TP}(\mathrm{am}-$ monium nitrogen $\&$ total phosphorus) were recorded at a small level of ca. 3-11\%. It should be rather interpreted as a result of the nature of statistically acceptable differences resulting from, for example, random sampling or measurements themselves, especially in stage procedures of colorimetric methods while performing tests etc. Significant differences were found in color - when PIX® 116 was used, periodically higher values of this parameter were recorded at the outflow by approx. 20-30\% (the effect of formation of $\left(\left[\mathrm{Fe}(\mathrm{Cl})_{\alpha}\right]^{(\alpha-3)}\right.$ type complexes with the excess of free forms of $\mathrm{Fe}^{3+}$ aq) than when PIX® 113 and PIX® 122 were used, because they contain sulphate salts [62, 69] which resulted from a different mobility and ionic strength of chlorides (PIX® 116) and sulphates (PIX® 113 and 122) $[62,70]$. Comparable levels, respectively 75 and $60 \%$ determined in stream $\mathrm{PW}_{(\mathrm{s})}$ were obtained for $\mathrm{COD}$ and $\mathrm{BOD}_{5}$, but not exceeding removal. 
Table 3 Removal levels (\%) or change of selected parameters of PW using coagulation with PIX® 113 and neutralized with the solution of 7.5\% $\mathrm{NaOH}^{\mathrm{a}-\mathrm{c})}$

\begin{tabular}{|c|c|c|c|c|}
\hline \multirow[t]{2}{*}{ No. } & \multirow[t]{2}{*}{ Parameter } & \multicolumn{3}{|c|}{$\%$ removal or change } \\
\hline & & Minimum value & Maximum value & Value of the median's ${ }^{d)}$ \\
\hline 1 & \multirow[t]{2}{*}{$\mathrm{pH}$} & 7.9 & 8.8 & 8.3 \\
\hline $1.1^{\mathrm{g})}$ & & 7.7 & 8.7 & 8.2 \\
\hline 2 & \multirow[t]{3}{*}{ Color } & 73 & 89 & 84 \\
\hline $2.1^{\mathrm{g})}$ & & 82 & 95 & 91 \\
\hline $2.2^{\mathrm{g})}$ & & 57 & 88 & 79 \\
\hline 3 & \multirow[t]{3}{*}{ TDS $^{\text {e) }}$} & 7 & 15 & 10 \\
\hline $3.1^{\mathrm{g})}$ & & 5 & 13 & 8 \\
\hline $3.2^{\mathrm{g})}$ & & 5 & 13 & 7 \\
\hline 4 & $\mathrm{TSS}^{\mathrm{f})}$ & $\operatorname{tr}^{\mathrm{fl})}$ & $\operatorname{tr}^{\mathrm{fl})}$ & $\operatorname{tr}^{\mathrm{fl})}$ \\
\hline 5 & COD & 48 & 67 & 55 \\
\hline $5.1^{\mathrm{g})}$ & $\mathrm{COD}_{\omega}^{\mathrm{h} 1)}$ & 46 & 64 & 52 \\
\hline $5.2^{\mathrm{g})}$ & $\mathrm{COD}_{\omega}{ }^{\mathrm{h} 2)}$ & 39 & 57 & 48 \\
\hline 6 & \multirow{3}{*}{$\mathrm{BOD}_{5}$} & 34 & 51 & 41 \\
\hline $6.1^{\mathrm{g})}$ & & 36 & 50 & 42 \\
\hline $6.2^{\mathrm{g})}$ & & 29 & 44 & 35 \\
\hline 7 & $\mathrm{EE}^{\mathrm{i})}$ & $\operatorname{tr}$ & $\operatorname{tr}$ & $\operatorname{tr}$ \\
\hline 8 & \multirow[t]{3}{*}{$\mathrm{TN}$} & 12 & 24 & 17 \\
\hline $8.1^{\mathrm{g})}$ & & 9 & 19 & 14 \\
\hline $8.2^{\mathrm{g})}$ & & 11 & 22 & 17 \\
\hline 9 & \multirow[t]{3}{*}{ AN } & 5 & 12 & 8 \\
\hline $9.1^{\mathrm{g})}$ & & 3 & 9 & 7 \\
\hline $9.2^{\mathrm{g})}$ & & 4 & 11 & 7 \\
\hline 10 & \multirow[t]{3}{*}{$\mathrm{TP}$} & 74 & 91 & 84 \\
\hline $10.1^{\mathrm{g})}$ & & 75 & 88 & 81 \\
\hline $10.2^{\mathrm{g})}$ & & 71 & 85 & 78 \\
\hline 11 & $\mathrm{HMs}^{\mathrm{i})}$ & 48 & 86 & 73 \\
\hline
\end{tabular}

where:

${ }^{\text {a) }}$ results are presented here for operational conditions where removal was determined based on measurements at points B and C (Fig. 1) excluding incidental exceedances of the limit neutralization reaction level $(\mathrm{pH})$ given below in reference ${ }^{\mathrm{b})}$ and described in the text below;

b) the process was carried out with the control of uniformity of mixing the reagents using the process $\mathrm{pH}$-meters at the inlet (pH 1) and outlet (pH 2) of the

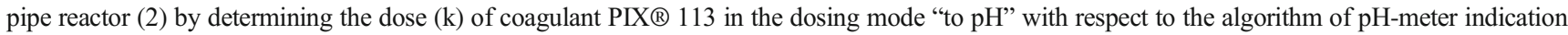
$(\mathrm{pH} 1)$ and the dose (n) of aqueous solution of $7.5 \% \mathrm{NaOH}$ with reference to the dose of PIX® 113 coagulant in programmed relationships, with reaching calculated value of $\mathrm{pH}_{(\mathrm{PIX} 113)}=1.2 \mathrm{pH}_{(7.5 \% \mathrm{NaOH})}$ respectively, but with keeping the additionally set upper threshold value after the neutralization at $\mathrm{pH}=8.8$;

${ }^{\text {c) }}$ the retention time of the effluents (the total flow time) in the process chambers (3.1) and (3.3) of the AR (Fig. 1) for the procedures of experimental series was set at the level $90.0 \pm 3.0 \mathrm{~min}$;

d) the median $\left(\mathrm{m}_{1 / 2}\right)$ in $\%$ of the removal levels (or the parameter change rate) determined basing on measurement series, for which the ranges of parameter values of the incoming wastewater are given in Table 1;

e) it is given here the level of removal determined by the relationship: $\eta_{(\mathrm{TDS})}=\left\{\left[1-\left(\left(\operatorname{TDS}_{(\mathrm{RW}(\mathrm{s}))}-\mathrm{TDS}_{(\mathrm{PW})}+\operatorname{TDS}_{(\mathrm{k})(\mathrm{n})}\right) / \operatorname{TDS}_{(\mathrm{RW}(\mathrm{s}))}\right)\right]\right\} 100 \%($ where: $\eta_{\text {(TDS })}$ - the level of removal of TDS parameters in \% determined at the outlet - the samples taken at point $\mathrm{C}($ Fig. 1$), \mathrm{TDS}_{(\mathrm{RW}(\mathrm{s}))}-$ the inlet level the samples taken at point B (Fig. 1) and $\operatorname{TDS}_{(\mathrm{PW})}-\mathrm{TDS}$ the load pool removed by coagulation (k) and neutralization $\left.(\mathrm{n}), \mathrm{TDS}_{(\mathrm{k})(\mathrm{n})}\right)-$ the pool of external load carried in with (k) PIX® 113 coagulant and (n) neutralizing reagent $(7.5 \% \mathrm{NaOH})$;

f) the use of multilayer gravel filter (4) (Fig. 1) results in PW and full removal of dispersed phases (TSS \& EE) and $\mathrm{T}_{\mathrm{a}}$ parameter, also in case of preliminary disinfection testing with $1.0 \% \mathrm{H}_{2} \mathrm{O}_{2}$ or $1.5 \% \mathrm{CH}_{3} \mathrm{COOOH}$ (where ${ }^{\mathrm{fl})}$ : $\mathrm{tr}$ - total removal);

g) No. 1.1, 2.1, 3.1, 5.1, 6.1 and 8.1 to 10.1 series of determinations (12 series) after initial disinfection of rolling stock surfaces using $1.0 \%$ solution $\mathrm{H}_{2} \mathrm{O}_{2}$ and then typical aqueous treatment washing and No. 2.2, 3.2, 5.2, 6.2 and 8.2-10.2 series of determinations (15 series) after initial disinfection of rolling stock surfaces using $1.5 \% \mathrm{CH}_{3} \mathrm{COOOH}$ and then typical washing (HMs parameter was not analyzed for these cases);

$\mathrm{h}_{1}$ and $\left.\mathrm{h} 2\right)$ for samples with pre-disinfection ${ }^{\mathrm{h} 1)} 1.0 \% \mathrm{H}_{2} \mathrm{O}_{2}$ or ${ }^{\mathrm{h} 2)} 1.5 \% \mathrm{CH}_{3} \mathrm{COOOH}$ COD parameter was given on the basis of the relation: $\mathrm{COD}_{\omega}=$ $\mathrm{COD} v-\varphi \Psi$

i) the use of a multilayer gravel filter (4) (Fig. 1) resulted in a clear effluent and a complete removal of dispersed phases (TSS \& EE) and the $\mathrm{T}_{\mathrm{a}}$ parameter, also when pre-disinfection is tested with $1.0 \% \mathrm{H}_{2} \mathrm{O}_{2}$ or $1.5 \% \mathrm{CH}_{3} \mathrm{COOOH}$ (where: $\mathrm{tr}$ - total removal) 


\section{Oxidant effect}

The application of pre-oxidation before the coagulation treatment stage in this technological variant did not lead to any significant improvements in the parameters of $\mathrm{PW}$ at the outlet of the installation, but it often complicated considerably the process, especially after the application of aqueous $\mathrm{H}_{2} \mathrm{O}_{2}$ solution (Tables 3 and 4. No. 2.1, 3.1, 5.1, 6.1, 8.1-10.1). This was probably due to the occurring residual processes based on catalytic reactions involving mainly $\mathrm{Fe}(\mathrm{III})$ aquacomplexes, $\mathrm{Fe}(\mathrm{III})$-hydroxycomplexes (e.g. $[\mathrm{FeOH}]^{2+}$, $\left[\mathrm{Fe}(\mathrm{OH})_{2}\right]^{+}$and $\left.\left[\mathrm{Fe}_{2}(\mathrm{OH})_{2}\right]^{4+}[71,72]\right)$ as well as $\mathrm{Fe}(\mathrm{III})$-hydroxy-peroxycomplexes $\left(\mathrm{Fe}^{\mathrm{III}}\left(\mathrm{HO}_{2}\right)^{2+}\right.$ and $\left[\mathrm{Fe}^{\mathrm{III}}(\mathrm{OH})\left(\mathrm{HO}_{2}\right)\right]^{+}$ $[73,74])$. This resulted in $\mathrm{H}_{2} \mathrm{O}_{2}$ decomposition according to a
Table 4 Removal levels (\%) of selected parameters of the PW by means of double-stage coupled acid-alkali coagulation using $\left(\mathrm{I}^{\mathrm{O}}\right)$ PIX® $116-\left(\mathrm{II}^{\circ}\right)$ SAX® 18 system $^{\text {a) }}$

\begin{tabular}{|c|c|c|c|c|}
\hline \multirow[t]{2}{*}{ No. } & \multirow[t]{2}{*}{ Parameter } & \multicolumn{3}{|c|}{$\%$ removal or change } \\
\hline & & Minimum value & Maximum value & Value of the median's $\left.{ }^{b}\right)$ \\
\hline 1 & $\mathrm{pH}$ & 8.1 & 8.8 & 8.3 \\
\hline $1.1^{\mathrm{f})}$ & & 8.2 & 8.7 & 8.1 \\
\hline 2 & Color & 79 & 94 & 91 \\
\hline $2.1^{\mathrm{f})}$ & & 66 & 91 & 86 \\
\hline 3 & $\operatorname{TDS}^{\mathrm{c})}$ & 6 & 15 & 11 \\
\hline $3.1^{\mathrm{f})}$ & & 6 & 11 & 9 \\
\hline 4 & $\mathrm{TSS}^{\mathrm{d})}$ & $\operatorname{tr}^{\mathrm{d} 1)}$ & $\operatorname{tr}^{\mathrm{d} 1)}$ & $\operatorname{tr}^{\mathrm{d} 1)}$ \\
\hline 5 & $\mathrm{COD}$ & 49 & 69 & 59 \\
\hline $5.1^{\mathrm{f})}$ & $\mathrm{COD}_{\omega}{ }^{\mathrm{g})}$ & 43 & 72 & 59 \\
\hline 6 & $\mathrm{BOD}_{5}$ & 38 & 52 & 43 \\
\hline $6.1^{\mathrm{f})}$ & & 32 & 47 & 39 \\
\hline 7 & $E E^{d)}$ & $\operatorname{tr}$ & $\operatorname{tr}$ & $\operatorname{tr}$ \\
\hline 8 & $\mathrm{TN}$ & 11 & 31 & 24 \\
\hline $8.1^{\mathrm{f})}$ & & 9 & 25 & 21 \\
\hline 9 & AN & 7 & 18 & 11 \\
\hline $9.1^{\mathrm{f})}$ & & 6 & 14 & 11 \\
\hline 10 & $\mathrm{TP}$ & 78 & 89 & 84 \\
\hline 10. $1^{\mathrm{f})}$ & & 75 & 84 & 78 \\
\hline 11 & $\mathrm{HMs}^{\mathrm{e})}$ & 68 & 87 & 81 \\
\hline
\end{tabular}

where:

a) $\left(\mathrm{I}^{\mathrm{o}}\right)$ : acid coagulant PIX ${ }^{\circledR} 116,\left(\mathrm{II}^{\mathrm{o}}\right)$ : $\mathrm{SAX}{ }^{\circledR} 18$ alkaline coagulant according to the data of the safety data in Table 2. Doses of coagulants were introduced into the pipe reactor (2) (Fig. 1) in the "up to pH" mode to control the uniformity of mixing the reagents using process $\mathrm{pH}$-meters at the inlet $(\mathrm{pH} 1)$ and outlet $(\mathrm{pH} 2)$. In this dosing mode, the first-dose coagulant was dosed in relation to the $\mathrm{pH}$-meter indication algorithm $(\mathrm{pH} 1)$ at the reactor inlet (2) and the second-dose coagulant was regulated in relation to the first-dose coagulant at $\mathrm{pH}_{(\mathrm{PIX} 116)}=1.2$ $\mathrm{pH}_{(\mathrm{SAX} 18)}$, respectively, but the programmed limit of $\mathrm{pH}$ after the second coagulation stage was maintained at the level not exceeding $\mathrm{pH}=8.8$;

${ }^{\text {b) }} \mathrm{m}_{1 / 2}$ - median ( $1 / 2$ order) determined on the basis of 22 series of measurements carried out over two quarters, maintaining the retention time in process volumes (3.1) and (3.2) (Fig. 1) analogous to those given in reference ${ }^{\mathrm{c})}$ Table 3, determining the removal on the basis of measurements in points B and C (Fig. 1) and at the level of determined values of RW parameters within the limits given in Table 1;

${ }^{c)}$ the removal level for stream $\mathrm{RW}_{(\mathrm{s})}$ is given in reference ${ }^{\mathrm{e})}$ to Table 3;

d) the use of a multilayer gravel filter (4) (Fig. 1) resulted in a clear effluent (full removal of $\mathrm{T}_{\mathrm{a}}$ ) and of total dispersion phase removal (EE \& TSS), even after tests with $1.0 \% \mathrm{H}_{2} \mathrm{O}_{2}$ pre-disinfection (where ${ }^{\mathrm{d} 1)}$ : $\operatorname{tr}-$ total removal);

e) the sum of $\mathrm{HMs}$ : $\mathrm{Cd}, \mathrm{Cr}_{(\mathrm{T})}, \mathrm{Cu}, \mathrm{Hg}, \mathrm{Mn}, \mathrm{Ni}, \mathrm{Pb}, \mathrm{Zn}$ - this parameter was taken into account when the concentration of any of them exceeded the level of $0.1 \mathrm{mg} \mathrm{l}^{-1}$ - such concentrations were found in 14 samples taken (determined as $\mathrm{m}_{1 / 2(\mathrm{HMs})}=1.69 \mathrm{mg} \mathrm{l}^{-1}$ ) from 22 process batches (no concentrations of $\mathrm{Cd}, \mathrm{Cr}_{(\mathrm{T})}$ and $\mathrm{Hg}$ exceeding the level of $0.1 \mathrm{mg} \mathrm{l}^{-1}$ were found in any of the samples);

${ }^{\mathrm{f})}$ the series of determinations ( 14 series) after the initial disinfection of rolling stock surfaces using $1.0 \% \mathrm{H}_{2} \mathrm{O}_{2}$ and then typical washing (HMs parameter not analyzed in these cases);

${ }^{\text {g) }} \mathrm{COD}$ parameter is presented as $\mathrm{COD}_{\omega}$ based on the relation given in footnotes ${ }^{\text {h1) }}$ to Table 3 
number of radical, radical-ionic and ionic reactions, known from the literature, e.g. [71, 72, 75-77]: $\mathrm{Fe}^{3+}+\mathrm{H}_{2} \mathrm{O}_{2} \leftrightarrow$ $\mathrm{Fe}^{\mathrm{IIII}}\left(\mathrm{HO}_{2}\right)^{2+}+\mathrm{H}^{+} ; \mathrm{Fe}^{\mathrm{III}}\left(\mathrm{HO}_{2}\right)^{2+}+\mathrm{H}_{2} \mathrm{O}_{2} \rightarrow \mathrm{Fe}^{2+} \mathrm{aq}+\mathrm{HO}_{2}{ }^{-}$, $\mathrm{Fe}^{\mathrm{III}}\left(\mathrm{HO}_{2}\right)^{2+}+\mathrm{H}_{2} \mathrm{O}_{2} \leftrightarrow \mathrm{Fe}^{\mathrm{III}}(\mathrm{OH})\left(\mathrm{HO}_{2}\right)^{+}$, $\mathrm{Fe}^{\mathrm{III}}(\mathrm{OH})\left(\mathrm{HO}_{2}\right)^{+} \rightarrow \mathrm{Fe}^{2+}$ aq $+\mathrm{HO}_{2}{ }^{-}+\mathrm{OH}^{-}, \mathrm{Fe}^{3+} \mathrm{aq}+$ $\mathrm{HO}_{2}{ }^{\circ} \rightarrow \mathrm{Fe}^{2+} \mathrm{aq}+\mathrm{O}_{2}+\mathrm{H}^{+}, \mathrm{Fe}^{3+} \mathrm{aq}+\mathrm{HO}^{\cdot} \rightarrow \mathrm{FeOH}^{3+} \rightarrow$ $\mathrm{FeO}^{2+} \mathrm{aq}+\mathrm{H}^{+}, 2 \mathrm{Fe}^{3+} \mathrm{aq}+\mathrm{H}_{2} \mathrm{O}_{2} \rightarrow 2 \mathrm{Fe}^{2+} \mathrm{aq}+\mathrm{O}_{2}+2 \mathrm{H}^{+}$etc. During these transformations, the reactions (at least at the residual level), which are described in the literature as Haber-Weiss or Haber-Willstätter systems, and a whole series of reactions initiated by the presence of $\mathrm{Fe}$ (II) iron, typical for the transformations of Fenton system, e.g. [76, 78-84], have certainly had a significant role: $\mathrm{Fe}^{2+}$ aq $+\mathrm{H}_{2} \mathrm{O}_{2} \rightarrow \mathrm{Fe}^{3+} \mathrm{aq}+$ $\mathrm{HO}^{\circ}+\mathrm{OH}^{-}, \mathrm{Fe}^{2+}$ aq $+\mathrm{H}_{2} \mathrm{O}_{2} \rightarrow \mathrm{FeO}^{2+}$ aq $+\mathrm{H}_{2} \mathrm{O}, \mathrm{FeO}^{2+}$ aq + $\mathrm{H}_{2} \mathrm{O}_{2} \rightarrow \mathrm{Fe}^{2+} \mathrm{aq}+\mathrm{O}_{2}$, and the reaction of $\mathrm{Fe}(\mathrm{II})$ with radical products, $\mathrm{Fe}^{2+} \mathrm{aq}+\mathrm{HO}^{\circ} \rightarrow \mathrm{Fe}^{3+} \mathrm{aq}+\mathrm{OH}^{-}, \mathrm{Fe}^{2+} 2027 \mathrm{aq}+$ $\mathrm{HO}_{2}{ }^{-} \rightarrow \mathrm{Fe}^{3+} \mathrm{aq}+\mathrm{HO}_{2}^{-}$etc. The effect of very probable parallel course of these side reactions to the coagulation $(\mathrm{k})$ was significant foaming, taking place on the surface of the process volume (3.1) of AR chamber (3). It also induced an increase in color and turbidity levels, as well as a simultaneous worsening of separation process of sedimentation of precipitated and flocculated phases in the volume of process chamber (3.3). It was also manifested in a complete disappearance of an irregular phase of the suspended bed (upflow sludge blanket), at $3.3-4.7 \mathrm{~m} \mathrm{~h}^{-1}$ of flow rate through this volume, resulting in a decrease in quality of the wastewater directed onto the filtration stage, which forced the necessity to backflush the filter (4) more frequently and it also included an increase in the total volume of backflush wastewater directed into the intermediate tank (8).

\section{Double-stage coagulation}

The application of double-stage coagulation based on iron (III) and aluminum (III) coagulants, such as PIX® $116-$ SAX® 18 system, did not lead to any significant increases in removal levels of analyzed wastewater parameters (Table 4) in relation to PIX® $113-7.5 \% \mathrm{NaOH}$ system (Table 3). The obtained removal levels were comparable, but the volume and dry mass of post-coagulation sludge increased significantly (ca. 15-35\%), which was mainly a function of the increase in the share of polynuclear hydrolysis products initiated by the intermediate ionic forms such as $\mathrm{Al}_{13} \mathrm{O}_{4}(\mathrm{OH})_{24}{ }^{7+}[69,85]$ and/or $\mathrm{Al}_{8}(\mathrm{OH})_{20}{ }^{4+}[86]$.

Pairs of reagents at flow rates $2.8-4.1 \mathrm{~m} \mathrm{~h}^{-1}$ for PAX® 16 - SAX® 18 and 2.2-3.5 m h${ }^{-1}$ for PAX® 18 - SAX® 18, in chamber (3.3) allowed producing an irregular and suspended layer in the presence of the residual amounts of particles that did not flocculate and settle due to their size and the level of linear flow rate. The presence of this specific suspended bed (sludge blanket) additionally improved the clarity of PW directed to another process node (4) (Fig. 1).
The application of double-stage coagulation with aluminum reagents additionally induced co-precipitation, which also included dissolved natural organic matter, manifested by the increase in the removal of dissolved loads, not to be obtained using the single-stage coagulation variant with neutralization [62]. This co-precipitation as the method to increase the elimination level of soluble contamination load is inseparably connected with the polynuclear hydrolysis of aluminum products with a dominant share of crystalline or amorphous structures and their mutual mixed forms, generated after exceeding the thresholds of their precipitation during neutralization and a parallel second degree of coagulation connected with neutralization. Then, during the formation of floccular structures, a specific closure of soluble impurities and nanodispersion occurs, which results in a measurable increase in removal of load, especially COD and $\mathrm{BOD}_{5}[62,69,73,74$, 85-91]. In the variant of double-stage coagulation based on aluminum (III) salts, of the initiation of these phenomena is connected with the formation of increased volume of sediments with a significantly developed sorption surfaces also enabling measurable removal of salinity caused by labile anionic or cationic forms or their coordination combinations being a part of the total salinity load pool $[62,68,71]$. A side effect of these processes may be partial sorption of the pool of dissolved substances on surfaces of products hydrolysis of coagulants and co-precipitation processes.

\section{Oxidative effect}

Application of preliminary pre-oxidation of the wastewater, especially using $\mathrm{H}_{2} \mathrm{O}_{2}$, does not lead to an increase in the amount of troublesome sludge treated wastewater and does not cause higher secondary salinity. However, its use in the case studied here should be considered only for the use of coupled coagulation based on aluminum coagulants, e.g. PAX® 16 (PAX® 18) - SAX® 18, etc. Then, for such combinations of coagulants, you will avoid: 1) destructive catalytic activity of $\mathrm{Fe}(\mathrm{III})$, occuring after the application of the systems with PIX® reagents with reference to oxidizing disinfectants $\left(\mathrm{CH}_{3} \mathrm{COOOH}\right.$ or $\left.\mathrm{H}_{2} \mathrm{O}_{2}\right)$ and 2) adverse secondary quality effects (e.g. salinity $\left.\left(\operatorname{TDS}_{(\mathrm{ox})}\right)\right)$ being a result of mineralization of the organic load by the introduced oxidants. In full technological scale, using the double-stage coagulation coupled with aluminum salts (PAX® 16 (or PAX® 18) SAX® 18 or SAX® 18 - PAX® 16 (or PAX® 18)), no significant effect indicator reagents used for pre-oxidation on the removal level of contaminants in the tested wastewater was found and the results were at the level obtained during pretreatment without pre-oxidation (Table 5). Basic components of aluminum coagulants: aluminum and polyaluminum chloride in acid coagulants (PAX® 16 and 18) and sodium aluminate in alkaline coagulant (SAX® 18), in the environment of tested wastewater were chemically inert towards $\mathrm{H}_{2} \mathrm{O}_{2}$, 
Table 5 Comparison (\%) of removal levels of selected parameters for PW with doublestage coagulation in acidic and alkaline $\left(\mathrm{I}^{\mathrm{O}}-\mathrm{II}^{\mathrm{O}}\right)^{\mathrm{a}, \mathrm{c})}$ and alkalineacidic options $\left(\mathrm{II}^{\mathrm{o}}-\mathrm{I}^{\mathrm{o}}\right)^{\mathrm{b}, \mathrm{c})}$ using aluminum coagulants

\begin{tabular}{|c|c|c|c|c|}
\hline \multirow[t]{2}{*}{ No. } & \multirow[t]{2}{*}{ Parameter } & \multicolumn{3}{|c|}{$\%$ removal or change ${ }^{\mathrm{d})}$} \\
\hline & & $\begin{array}{l}\text { Minimum value } \\
\left(\mathrm{I}^{\mathrm{o}}-\mathrm{II}^{\mathrm{o}}\right)\left(\mathrm{II}^{\mathrm{o}}-\mathrm{I}^{\mathrm{o}}\right)\end{array}$ & $\begin{array}{l}\text { Maximum value } \\
\left(\mathrm{I}^{\mathrm{o}}-\mathrm{II}^{\mathrm{o}}\right)\left(\mathrm{II}^{\mathrm{o}}-\mathrm{I}^{\mathrm{o}}\right)\end{array}$ & $\begin{array}{l}\text { Value of the median's } \\
\left(\mathrm{I}^{\mathrm{o}}-\mathrm{II}^{\mathrm{o}}\right)\left(\mathrm{II}^{\mathrm{o}}-\mathrm{I}^{\mathrm{o}}\right)\end{array}$ \\
\hline 1 & $\mathrm{pH}^{\mathrm{c})}$ & 7.97 .8 & 8.78 .6 & 8.28 .1 \\
\hline 2 & Color & 8392 & $\operatorname{tr} \operatorname{tr}$ & $\operatorname{tr} \operatorname{tr}$ \\
\hline 3 & $\operatorname{TDS}^{\mathrm{f}}$ & 57 & 1115 & 810 \\
\hline 4 & $\mathrm{TSS}^{\mathrm{g})}$ & $\operatorname{tr}^{\mathrm{g})} \operatorname{tr}^{\mathrm{g})}$ & $\operatorname{tr}^{\mathrm{g})} \operatorname{tr}^{\mathrm{g})}$ & $\operatorname{tr}^{\mathrm{g})} \operatorname{tr}^{\mathrm{g})}$ \\
\hline 5 & COD & 5449 & 6169 & 6164 \\
\hline 6 & $\mathrm{BOD}_{5}$ & 3741 & 5451 & 4243 \\
\hline 7 & $\mathrm{EE}^{\mathrm{h})}$ & $\operatorname{tr} \operatorname{tr}$ & $\operatorname{tr} \operatorname{tr}$ & $\operatorname{tr} \operatorname{tr}$ \\
\hline 8 & $\mathrm{TN}$ & 1315 & 2731 & 1924 \\
\hline 9 & AN & 912 & 1924 & 1412 \\
\hline 10 & $\mathrm{TP}$ & 8189 & 9395 & 9091 \\
\hline 11 & $\left.\mathrm{HMs}^{\mathrm{h}}\right)$ & 7566 & 8489 & $77^{\mathrm{h} 1)} 81^{\mathrm{h} 2)}$ \\
\hline
\end{tabular}

where:

a and b) $\mathrm{I}^{\mathrm{o}}$ (or $\mathrm{II}^{\mathrm{o}}$ ): acid coagulant PAX® 18 and $\mathrm{II}^{\mathrm{o}}$ (or $\mathrm{I}^{\mathrm{o}}$ ): basic coagulant $\mathrm{SAX} ® 18$ according to the data in Table 2. The notations $\left(\mathrm{I}^{\mathrm{o}}-\mathrm{II}^{\mathrm{o}}\right)$ and $\left(\mathrm{II}^{\mathrm{o}}-\mathrm{I}^{\mathrm{o}}\right)$ denote the sequence options for dosing into the continuous flow pipe reactor (2) (in Fig. 1) of coagulant doses introduced in "up-to-pH" mode to control the uniformity of mixing the reagents using process $\mathrm{pH}$-meters at the inlet $(\mathrm{pH} 1)$ and outlet $(\mathrm{pH} 2)$. In such dosing mode, the first-stage coagulant dose $\left(\mathrm{I}^{\mathrm{o}}\right)$ was metered according to $\mathrm{pH}$-meter indication algorithm $(\mathrm{pH} 1)$ at the reactor inlet (2), whereas the second-stage coagulant dose $\left(\mathrm{II}^{\mathrm{o}}\right)$ was regulated by program with reference to the first-stage coagulant dose according to the set relation: $\mathrm{pH}_{(\mathrm{PAX} 18)}=1.2 \mathrm{pH}_{(\mathrm{SAX} 18)}$ or $\mathrm{pH}_{(\mathrm{SAX} 18)}=1.2 \mathrm{pH}_{(\mathrm{PAX} 18)}$, respectively but not exceeding the upper limit of $\mathrm{pH}$ after the second stage $\mathrm{pH}=8.8$;

c) the effluents retention time (the total flow time) through the process chambers (3.1) and (3.2) of the AR (Fig. 1) was determined for the procedures of this experimental series at the same level as given in footnote ${ }^{\mathrm{c})}$ to Table 3;

d) the parameters of RW directed onto the test installation do not exceed the limit values and are within the ranges of values given in Table 1;

e) the median (order $1 / 2\left(\mathrm{~m}_{1 / 2}\right)$ ) determined on the basis of 19 measurement series for the coagulation option $\left(\mathrm{I}^{\mathrm{o}}-\mathrm{II}^{\mathrm{o}}\right)$ and 20 ones for the coagulation option $\left(\mathrm{II}^{\mathrm{o}}-\mathrm{I}^{\mathrm{o}}\right)$;

f) is the removal level determined using the same relationship as in ${ }^{\text {e) }}$ of Table 3;

${ }^{\mathrm{g})}$ removal levels guaranteed by additional protection in a form of final filtration stage as the unit of multi-layer gravel bed (4) (Fig. 1) similarly to the other tested coagulation options (where ${ }^{\mathrm{g})}: \operatorname{tr}$ - total removal);

h) the value of the determined sum of $\mathrm{HMs}$ (where $\mathrm{HMs}: \mathrm{Cd}, \mathrm{Cr}_{(\mathrm{T})}, \mathrm{Cu}, \mathrm{Ni}, \mathrm{Pb}$ and $\mathrm{Zn}$ ) is given for the individual process batches, when the concentrations of individual recorded in the RW exceeded level $0.1 \mathrm{mg} \mathrm{l}^{-1}$ and such levels were found for ${ }^{\mathrm{h} 1)}$ in 10 (determined as $\mathrm{m}_{1 / 2(\mathrm{HMs})}=1.66 \mathrm{mg} \mathrm{l}^{-1}$ ) and for ${ }^{\mathrm{h} 2)}$ in 9 (determined as $\mathrm{m}_{1 / 2(\mathrm{HMs})}=$ $2.89 \mathrm{mg} \mathrm{l}^{-1}$ ) process batches (no $\mathrm{Cd}, \mathrm{Cr}_{(\mathrm{T})}, \mathrm{Hg}$, and Ni concentrations exceeding $0.1 \mathrm{mg} \mathrm{l}^{-1}$ were found in any sample) without causing its decomposition or blocking, e.g. by coordination.

In practice, the pre-disinfection using $\mathrm{H}_{2} \mathrm{O}_{2}$ may be considered, but using such doses that result in limited pre-coagulation. At the same time, this stage and the decomposition resulting from the complex disinfection activity exhausts the mass of the oxidant circulating without its level of free unused concentration directed to the subsequent treatment stages. Such a solution, with permanently changed parameters of treated RW, will make the use of system significantly more difficult, which will be related to the necessity of current analytical assessment of $\mathrm{H}_{2} \mathrm{O}_{2}$ demand for the purposes of disinfection and precoagulation.

\section{Biological hazard}

Based on literature data [92-95], it was assumed that potential germs, which may periodically occur in the generated wastewater, in a predominant number of units, will not be isolated in single units but will be mainly grouped in particles, clumps or lumps of biologically active colloidal-suspended fractions and surrounded by substances protecting them. It was found that substances accompanying pathogenic microorganisms formed with them, e.g. in aggregates, suspended solids or larger particles of pollutants, which will not be coagulated and/or flocculant condensed and settled to the sludge accumulated in pockets (3.4) of AR, can be effectively filtered out. In the case of free-floating microorganisms with an external 
structure that prevents their coagulation and/or flocculation, the use of $\mathrm{CH}_{3} \mathrm{COOOH}$ or $\mathrm{H}_{2} \mathrm{O}_{2}$ as pre-oxidation is provided for. Applying these reagents as chemicals was aimed at causing destruction and modification of external structures of freefloating pathogenic organisms by oxidation and precoagulation accompanying the pre-disinfection and then a complementary coagulation and/or flocculation in the process volumes of AR, leading to eliminate these organisms maximally. The residual amounts of them were eliminated in the volume of the filtration bed of the process unit (4). This way, filtration was an important initial step for the disinfection of the pretreated stream of effluents intended for reuse. In addition, to eliminate risks associated with the development of a biological membrane containing pathogens originated from the RW, an optional disinfection of the filter gravel bed (4) was provided for backflushing with water containing $\mathrm{CH}_{3} \mathrm{COOOH}$ or $\mathrm{H}_{2} \mathrm{O}_{2}$ water, supplied from tank (12) using a separate membrane pump (12.2) with an individual adjustment of metering the disinfectant. This procedure was applied incidentally and preventively, due to a lack of risk of the occurrence pathogenic microbial infections of the PW. The level of CFU determined at $22{ }^{\circ} \mathrm{C}$ after filtration (in samples collected at point $\mathrm{C}$ in Fig. 1) was recorded for each sample significantly below the threshold value of $100 \mathrm{CFU} \mathrm{ml}^{-1}$. No pathogenic bacteria of the genera Clostridium perfringens, Salmonella $s p$. and Shigella $s p$. was found in the samples of RW and PW collected for periodic evaluation. Microscopic analysis also did not reveal the presence of helminth spores of genera grouped in ATT parameter (Ascaris sp., Trichuris sp. and Toxacara sp.) and cysts and/or trophozoites of Cryptosporidium parvum, Giardia lamblia or Entamoeba histolytica were not identified. During the research, the problem of pathogenic mycological and parasitological loads did not occur. However, it does not mean at all that it will not be significant even at the levels of irregular incidental short or long-term infections, which requires protection in form of filtration and disinfection procedures.

\section{Conclusions}

1. The continuous flow installation based on an accelator type two-chamber reactor is an appropriate technical solution enabling effective pretreatment and the reuse of sanitary safe, treated wastewater resulting from washing dirty surfaces of railway rolling stock of class $\mathrm{G}, \mathrm{H}, \mathrm{T}$ and, incidentally, class $\mathrm{F}$.

2. The highest efficiency measured by the removal level of indicator values such as TSS, EE, color, $\mathrm{COD}$ and $\mathrm{BOD}_{5}$ and satisfactory repeatability of removal is obtained by using double-stage, coupled acid/alkali or alkaline/acid coagulation with the use of aluminum coagulants in coagulation pairs, e.g. PAX ${ }^{\circledR}$ type (16 or 18 ) and alkaline
SAX® type 18 coagulants with a final flocculation and gravity phase separation and a complementary filtration under continuous flow conditions.

3. When pre-oxidation with aqueous solutions of peracetic acid or hydrogen peroxide is used, coupled coagulation based only on aluminum coagulants, e.g. PAX® $16-$ SAX® 18 or SAX® $18-$ PAX® 18 , with the help of which it is possible to achieve equal levels of removal of the basic indicator values and a sanitary clean stream of pretreated water with a CFU of $<100 \mathrm{ml}^{-1}$.

Acknowledgements The authors would like to express heartfelt thanks to the late Lech Zabłocki as a helpful contributor of this work and Projprzemeko ${ }^{\circledR}$ company (www.projprzemeko.pl) without the involvement of whom it would not have been possible to test effluents by the implemented new installation for treatment of wastewaters from the railway freight wagon wash.

\section{Declarations}

Conflict of interest The authors declare that they have no conflict of interest.

Open Access This article is licensed under a Creative Commons Attribution 4.0 International License, which permits use, sharing, adaptation, distribution and reproduction in any medium or format, as long as you give appropriate credit to the original author(s) and the source, provide a link to the Creative Commons licence, and indicate if changes were made. The images or other third party material in this article are included in the article's Creative Commons licence, unless indicated otherwise in a credit line to the material. If material is not included in the article's Creative Commons licence and your intended use is not permitted by statutory regulation or exceeds the permitted use, you will need to obtain permission directly from the copyright holder. To view a copy of this licence, visit http://creativecommons.org/licenses/by/4.0/.

\section{References}

1. Janić M. Advanced transport systems: operations and economics. London: (C) Springer-Verlag; 2014. p. 83-4. https://doi.org/10. 1007/978-1-4471-6287-2_3.

2. Crainig TG. Long-haul freight transportation. In Handbook of Transportation Science, International Series in Operations Research \& Management Science, Springer US 1999; 23:433491. https://doi.org/10.1007/978-1-4615-5203-1_13.

3. Kreutzberger ED. Distance and time in intermodal goods transport networks in Europe: a generic approach. Transp Res A. 2008;42(7): 973-93. https://doi.org/10.1016/j.tra.2008.01.012.

4. Bojovic N, Boskovic B, Milenkovic M, Sunjic A. A two-level approach to the problem of rail freight car fleet composition. Transport. 2010;25(2):186-92. https://doi.org/10.3846/transport. 2010.23.

5. Hansen I. Automated shunting of rail container wagons in ports and terminal areas. Transp Plan Technol. 2004;27(5):385-401. https:// doi.org/10.1080/0308106042000280501.

6. Bulis A, Škapars R. Development of international freight transit in Latvia. Procedia Soc Behav Sci. 2013;99:57-64. https://doi.org/10. 1016/j.sbspro.2013.10.471. 
7. Winebrake JJ, Corbett JJ, Falzarano A, Hawker JS, Korfmaker K, Ketha S, et al. Assessing energy, environmental, and economic tradeoffs in intermodal freight transportation. J Air Waste Manage Assoc. 2008;58(8):1004-13. https://doi.org/10.3155/1047-3289. 58.8.1004.

8. Burkhardt M, Rossi L, Boller M. Diffuse release of environmental hazards by railways. Desalination. 2008;226(1-3):106-13. https:// doi.org/10.1016/j.desal.2007.02.102.

9. Anderson P, Cunningham CJ, Barry DA. Efficiency and potential environmental impacts of different cleaning agents used on contaminated railway ballast. Land Contam Reclamat. 2002;10(2):71-7. https://doi.org/10.2462/09670513.609.

10. Awoleye EOA. A numerical model for the determination of track ballast life. In Railway Engineering-98, Proceedings of First International Conference on Maintenance \& Renewal of Permanent Way and Structures, Engineering Technical Press, Edinburgh. 10 July 1998 (ed. Forde M.C.), pp. 89-97.

11. Anderson P, Cunningham CJ, Barry DA. Gravimetric analysis of organic contamination in railway ballast. Land Contam Reclamat. 2000;8(2):71-4. https://doi.org/10.2462/09670513.559.

12. Vo PT, Ngo HH, Guo W, Zhou JL, Listowski A, Du B, et al. Stormwater quality management in rail transportation - past, present and future. Sci Total Environ. 2015;512-513:353-63. https:// doi.org/10.1016/j.scitotenv.2015.01.072.

13. Osborne $\mathrm{M}$, Montague $\mathrm{K}$. The potential for water pollution from railways. London, CIRIA, C643, UK. 2005.

14. Wiłkomirski B, Sudnik-Wójcikowska B, Galera H, Wierzbicka M, Malawska M. Railway transportation as a serious source of organic and inorganic pollution. Water Air Soil Pollut. 2011;218(1-4):33345. https://doi.org/10.1007/s11270-010-0645-0.

15. Baltrènas $P$, Vaitiekūnas $P$, Bačiulyte Ž. Investigation of soil's contamination with heavy metals by railway transport (Geležinkelio transporto taršos sunkiaisiais metalais dirvožemyje tyrimai ir ivvertinimas). J Environ Eng Landsc. 2009;17(4):244-51. https:// doi.org/10.3846/1648-6897.2009.17.244-251.

16. Ganorkar RA, Rode PI, Bhambhulkar AV, Godse PA, Chavan SL. Development of water reclamation package for wastewater from a typical railway station. Int J Innov Technol Res. 2014;2(2):841-6 http://ijitr.com/index.php/ojs/article/view/288/pdf.

17. Cao SC, Li YF, Li ZY, Qian XY, Xia L, Xu WL. Feasibility of railway washing wastewater disposal by improved CRI. Adv Mater Res. 1947-1950;2011:356-60. https://doi.org/10.4028/www. scientific.net/AMR.356-360.1947.

18. Li L. Design of railway washing wastewater treatment and reuse project. China Water \& Wastewater. 2000;16(4):34-6 http://caod. oriprobe.com/articles/2785799/Design_of_Railway_Washing Wastewater_Treatment_and.htm.

19. Liu CN, Bi DS. Treatment of train laundry wastewater for recycling. Adv Mater Res. 2011;393-395:1583-6. https://doi.org/ 10.4028/www.scientific.net/AMR.393-395.1583.

20. Afonso M. Contaminated railway ballast - reabilitation solutions and final destination. (Balastro contaminado das ferrovias - Suas repercussões, soluções de reabilitação e destino final. Dissertação de Mestrado Integrado em Engenharia Civil, Instituto Superior Técnico, Universidade Técnica de Lisboa); 2011; https://fenix. tecnico.ulisboa.pt/downloadFile/395143445909/Resumo\% 20alargado.pdf

21. Anderson P, Cunningham CJ, Hearnden RA, Barry DA, Philp JC. Optimisation and assessment of different railway ballast cleaning systems. Land Contam Reclam. 2003;11(4):397-403. https://doi. org/10.2462/09670513.628.

22. Ceney H. Selection of track form. In Railway Engineering-2001, Abstracts of the Fourth International Conference on Maintenance \& Renewal of Permanent Way; Power + Signalling; Structures + Earthworks, (ed. Forde M.C.). Engineering Technical Press, Edinburgh; 2001.
23. Collinson R. Ballast life \& maintenance. In Railway Engineering98, Proceedings of First International Conference on Maintenance $\&$ Renewal of Permanent Way and Structures, (ed. Forde M.C.), pp. 99-102. Engineering Technical Press, Edinburgh; 1998.

24. Department of the Environment, Transport and the Regions (DETR). A Better Quality of Life: A Strategy for Sustainable Development for the United Kingdom; 1999. Chapter 8, Section 8.62. www.gov.uk/government/uploads/system/uploads/ attachment_data/file/250882/5105.pdf

25. HMSO Aggregates Levy. Finance Act 2001. Chapter 9, Part 2; http://www.legislation.gov.uk/ukpga/2001/9/pdfs/ukpga 20010009_en.pdf

26. State of Florida Department of Environmental Protection. Fact Sheet: Terpene Cleaners Used for Industrial Cleaning. Florida's Pollution Prevention Program; 1995; http://www.wsppn.org/htm/ hub4/flap2com.htm

27. Plakhotnik VN, Onyshchenko JV, Yaryshkina LA. The environmental impacts of railway transportation in the Ukraine, Notes and comments. Transport Res D. 2005;10(3):263-8. https://doi.org/10. 1016/j.trd.2005.02.001.

28. Lan LW, Lin ETJ. Performance for railway transport: stochastic distance functions with inefficiency and ineffectiveness effects. J Transp Econ Policy. 2006;40(3):383-408; Article stable URL: http://www.jstor.org/stable/20053992

29. Railway Technical Publications, UIC Code: Catalogue of UIC Leaflets; 2015. www.uic.org

30. Poliakova VA, Lakshin AM, Pashinina OM, Zakharova TB, Dankina NK. Disinfection of the return water at stations for the washing of long-distance trains [Obezzarazhivanie oborotnoǐ vody na punktakh obmyvki poezdov dal'nego sledovaniia] Gigiena i sanitaria. 1979;1:84-85.

31. Klubkov VG, Bogdanov MV, Noarov IA, Nedomerkov IN, Polokhov ND, Spitsyna VM. Hygienic problems of protecting water reservoirs during washing of freight cars [Gigienicheskie problemy okhrany vodoemov pri obmyvke gruzovykh vagonov] Gigiena i sanitaria. 1995;5:53-54.

32. Poliakova VA, Gipp EK, Shashkovskii SG, Shashkovskii MG. Hygienic evaluation of the effectiveness of the use of impulse ultraviolet radiation sources in railway transport [Gigienicheskaia otsenka éffektivnosti primeneniia impul'snykh ul'trafioletovykh obluchatelei na zheleznodorozhnom transporte] Gigiena i sanitaria. 2000;2:20-21.

33. Zakharova TB, Poliakova VA. Improvement of disinfection measures in railway transport [O sovershenstvovanii dezinfektsionnykh meropriatii na zheleznodorozhnom transporte] Gigiena i sanitaria. 2000;4:59-61.

34. Muha R. Wastewater treatment model in washing stations for vehicles transporting dangerous goods. Promet-Traffic-Traffico. 2004;16(5):277-83 www.fpz.unizg.hr/traffic/index.php/ PROMTT/article/.../604/458.

35. Cao $\mathrm{W}, \mathrm{Hu} \mathrm{H}$. Pre-treatment of laundering wastewater by coagulation process. Journal of Henan University of Urban Construction. 4; 2009; http://en.cnki.com.cn/Article en/CJFDTOTALCJGZ200904014.htm

36. Kramer GR, Buyers A, Brownlee B. Electrolytic treatment of oily wastewater. Proceedings of the Industrial Waste Conference (34th Conference 8 May 1979 through 10 May 1979, Lafeyette, IN, USA); 1980. pp. 673-680.

37. Müller K. Electroflotation from the double layer to troubled waters. In Electrochemistry in Transition, edited by Murphy O.J. et all. Plenum Press, New York; 1992.

38. http://www.projprzemeko.pl/oczyszczanie-wod-obiegowych.html. Assessed 29 March 2021

39. https://www.kemira.com/water/products/ ?industry\%5Bwater\%5D=122. Assessed 29 March 2021. 
40. Polish Standards: reaction $(\mathrm{pH})(\mathrm{PN}-90 / \mathrm{C}-04540 / 01)$, color (PNEN ISO 7887:2012), total suspended solids (TSS) (PN-EN 872: 2007), etheric extract (EE) (PN-EN 1899-1-2002), chemical oxygen demand COD by dichromate method (PN-ISO 15705:2005), biochemical oxygen demand $\mathrm{BOD}_{\mathrm{n}}$ by the dilution method (PN-EN 1899-1:2002) (also $\mathrm{BOD}_{\mathrm{n}}$ determination method DIN EN 1899 H55 for Oxitop ${ }^{\circledR}$ Control set), total nitrogen (TN) (PN-73/C04576/12), ammonium nitrogen (AN) (PN-C-04576-4:1994) and total phosphorus (TP) (PN-EN 1189-2000).

41. APHA-AWWA-WEF: American Public Health Association, American Water Works Association, Water Environment Federation; 1998. Standard Methods for the Examination of Water and Wastewater (20th ed), ISBN 0875530478 , Washington, DC and Standard Methods for the Examination of Water and Wastewater, 22nd ed., APHA, Washington, D. C.; 2012.

42. U.S. Peroxide. Methods for residual peroxide determination: iodometric titration; 2003. Available from: http://www.h2o2.com/ intro/analytical/html

43. Awad MI, Oritani T, Ohsaka T. Simultaneous potentiometric determination of peracetic acid and hydrogen peroxide. Anal Chem. 2003;75(11):2688-93. https://doi.org/10.1021/ac0204707.

44. Sode F. Simultaneous determination of peracetic acid and acetic acid by titration with $\mathrm{NaOH}$. Anal Methods. 2014;6(7):2406-9. https://doi.org/10.1039/c3ay41836g.

45. Luukhonen T, Teeriniemi J, Prokkola H, Rämö J, Lassi U. Chemical aspects of peracetic acid based wastewater disinfection. Water SA. 2014;40(1):73-80. https://doi.org/10.4314/wsa.v40i1.9.

46. Kang YW, Cho MJ, Hwang KY. Correction of hydrogen peroxide interference on standard chemical oxygen demand test. Water Res. 1999;33(5):1247-51. https://doi.org/10.1016/S0043-1354(98) 00315-7.

47. Talinli I, Andreson GK. Interference of hydrogen peroxide on the standard COD test. Water Res. 1992;26(1):107-10. https://doi.org/ 10.1016/0043-1354(92)90118-N.

48. Zak S. Problem of correction of the chemical oxygen demand values determined in wastewaters treated by methods with hydrogen peroxide. Proc ECOpole. 2008;2(2):409-14 http://tchie.uni. opole.pl/ecoproc08b/Zak_08b.pdf.

49. Lee E, Lee H, Kim YK, Sohn K, Lee K. Hydrogen peroxide interference in chemical oxygen demand during ozone based advanced oxidation of anaerobically digested livestock wastewater. Int $\mathrm{J}$ Environ Sci Technol. 2011;8(2):381-8. https://doi.org/10.1007/ BF03326225.

50. American Public Health Association (APHA): Standard Methods for the Examination of Water and Wastewater, 21st edn., Washington; 2005;

51. USDA/FSIS Microbiology Laboratory Guidebook, 3rd edition, 1998 with revisions; 2014; Association of Official Analytical Chemists, Bacteriological Analytical Manual, 8-th Ed., Revision A, Washington; 1989; FDA Bacteriological Analytical Manual (BAM) online: https://www.fda.gov/Food/FoodScienceResearch/ LaboratoryMethods/ucm2006949.htm.

52. Collins and Lyne's Microbiological Methods 8th Edition, by Collins CH, Lyne PM, Grange JM, Falkinham III JO., Arnold, a member of the Hodder Headline Group, London; 2004.

53. Final Report and Executive Summaries from the AOAC International Presidential Task Force on Best Practices in Microbiological Methodology; August 2006.

54. Difco Manual of Dehydrated Culture Media and Reagents for Microbiological and Clinical Laboratory Procedures, 9th Edition, Difco Laboratories Incorporated; 1977.

55. International Organization for Standardization, Microbiologygeneral guidance on methods for the detection of Salmonella and Shigella. Ref. method ISO 6579-1:2017, Ref. method ISO 21567: 2004.

56. Merck Microbiology Manual 12th Edition; 2005.
57. The Oxoid Manual, by Bridson E.Y., Oxoid Ltd., 8th Ed., Basingstoke, England: Oxoid; 1998.

58. Hatam-Nahavandi K, Mahvi MM, Keshavarz H, Mobedi I, Rezaeian M. Detection of parasitic particles in domestic and urban wastewaters and assessment of removal efficiency of treatment plants in Tehran, Iran. Journal of Environmental Health Science \& Engineering. 2015;13(4):1-13. https://doi.org/10.1186/s40201015-0155-5.

59. Ayres RM, Mara DD. Analysis of wastewater for use in agriculture: a laboratory manual of parasitological and bacteriological techniques. Geneva: World Health Organization; 1996.

60. Żak S, Zabłocki L. Experimental set for testing methods of industrial wastewaters treatment with the use of flotation techniques. The 9th International Conference Environmental Engineering, 22-23 May 2014, Vilnius, Lithuania. https://doi.org/10.3846/enviro. 2014.101.

61. Richens DT. The chemistry of aqua ions. Chichester: Wiley; 1997.

62. Duan J, Gregory J. Coagulation by hydrolysing metal salts. Adv Colloid Interface Sci. 2003;100-102:475-502. https://doi.org/10. 1016/S0001-8686(02)00067-2.

63. Kitis M. Disinfection of wastewater with peracetic acid: A review. Environ Int. 2004;30(1):47-55. https://doi.org/10.1016/S01604120(03)00147-8.

64. De Laat J, Le GT, Legube B. A comparative study of the effects of chloride, sulfate and nitrate ions on the rates of decomposition of $\mathrm{H} 2 \mathrm{O} 2$ and organic compounds by $\mathrm{Fe}(\mathrm{II}) / \mathrm{H} 2 \mathrm{O} 2$ and $\mathrm{Fe}(\mathrm{III}) / \mathrm{H} 2 \mathrm{O} 2$. Chemosphere. 2004;55(5):715-23. https://doi.org/10.1016/j. chemosphere.2003.11.021.

65. Powell KJ, Brown PL, Byrne RH, Gajda T, Hefter G, Sjöberg S, et al. Chemical speciation of environmentally significant metals with inorganic ligands part 2: the $\mathrm{Cu} 2+-\mathrm{OH}-, \mathrm{Cl}-, \mathrm{CO} 32-, \mathrm{SO} 42$ -, and PO43- systems. Pure Appl Chem. 2007;79(5):895-950. https://doi.org/10.1351/pac200779050895.

66. Powell KJ, Brown PL, Byrne RH, Gajda T, Hefter G, Leuz AK, et al. Chemical speciation of environmentally significant metals with inorganic ligands part 3: the $\mathrm{Pb} 2+-\mathrm{OH}^{-}, \mathrm{Cl}-, \mathrm{CO} 32-, \mathrm{SO} 42$ -, and PO43- systems. Pure Appl Chem. 2009;81(12):2425-76. https://doi.org/10.1351/PAC-REP-09-03-05.

67. Powell KJ, Brown PL, Byrne RH, Gajda T, Hefter G, Leuz AK, et al. Chemical speciation of environmentally significant metals with inorganic ligands. Part 4: the $\mathrm{Cd} 2++\mathrm{OH}_{-}^{-}, \mathrm{Cl}-, \mathrm{CO} 32-$, SO42-, and PO43- systems. Pure Appl Chem. 2011;83(5):1163214. https://doi.org/10.1351/PAC-REP-10-08-09.

68. DeSmaele T, Moens L, Sandra P, Dams R. Determination of organometallic compounds in surface water and sediment samples with SPME-CGC-ICPMS. Microchim Acta. 1999;130(4):241-51. https://doi.org/10.1007/BF01242912.

69. Akitt JW, Greenwood NN, Khandelwal BL, Lester GD. 27Al nuclear magnetic resonance studies of the hydrolysis and polymerisation of the hexa-aquo-aluminium(III) cation. J Chem Soc Dalton Trans. 1972;5:604-10. https://doi.org/10.1039/DT9720000604.

70. Letterman RD, Vanderbrook SG. Effect of solution chemistry on coagulation with hydrolyzed Al(III): Significance of sulfate ion and pH. Water Res. 1983;17(2):195-204. https://doi.org/10.1016/00431354(83)90100-8.

71. Milburn RM, Vosburgh WC. A spectrophotometric study of the hydrolysis of iron(III) ion. II. Polynuclear species. J Am Chem Soc. 1955;77(5):1352-5. https://doi.org/10.1021/ja01610a084.

72. Knight RJ, Sylva RN. Spectrophotometric investigation of iron(III) hydrolysis in light and heavy water at $25^{\circ} \mathrm{C}$. J Inorg Nucl Chem. 1975;37(3):779-83. https://doi.org/10.1016/0022-1902(75)805392.

73. Murphy PJ, Posner AM, Quirk JP. Characterization of partially neutralized ferric chloride solutions. J Colloid Interface Sci. 1976;56(2):284-97. https://doi.org/10.1016/0021-9797(76)90254$\mathrm{X}$. 
74. Schneider W, Schwyn B. Aquatic Surface Chemistry, Stumm W. (Ed.), Wiley, New York; 1987. pp. 167-196.

75. De Laat J, Gallard H. Catalytic decomposition of hydrogen peroxide by $\mathrm{Fe}$ (III) in homogeneous aqueous solution: mechanism and kinetic modeling. Environ Sci Technol. 1999;33(16):2726-32. https://doi.org/10.1021/es981171v.

76. Kremer ML. "Complex" versus "free radical" mechanism for the catalytic decomposition of $\mathrm{H} 2 \mathrm{O} 2$ by ferric ions. Int J Chem Kinet. 1985;17(12):1299-314. https://doi.org/10.1002/kin.550171207.

77. Barb WG, Baxendale JH, George P, Hargrave KR. Reactions of ferrous and ferric ions with hydrogen peroxide. Part II. The ferric ion reaction. Trans Faraday Soc. 1951;47:591-616. https://doi.org/ 10.1039/TF9514700591.

78. Walling C, Weil T. The ferric ion catalyzed decomposition of hydrogen peroxide in perchloric acid solution. Int J Chem Kinet. 1974;6(4):507-16. https://doi.org/10.1002/kin.550060406.

79. Evans MG, George P, Uri N. The $[\mathrm{Fe}(\mathrm{OH})]+2$ and $[\mathrm{Fe}(\mathrm{O} 2 \mathrm{H})]+2$ complexes. Trans Faraday Soc. 1949;45:230-6. https://doi.org/10. 1039/TF9494500230.

80. Neyens E, Baeyens J. A review of classic Fenton's peroxidation as an advanced oxidation technique. J Hazard Mater. 2003;98(1-3): 33-50. https://doi.org/10.1016/S0304-3894(02)00282-0.

81. Wang JL, Xu LJ. Advanced oxidation processes for wastewater treatment: formation of hydroxyl radical and application. Crit Rev Env Sci Tec. 2012;42(3):251-325. https://doi.org/10.1080/ 10643389.2010.507698.

82. Koppenol WH. The Haber-Weiss cycle -70 years later. Redox Rep. 2001;6(4):229-34. https://doi.org/10.1179/ 135100001101536373.

83. Gallard H, De Laat J, Legube B. Influence du $\mathrm{pH}$ sur la vitesse d'oxydation de compose's organiques par FeII/H2O2. Me'canismes re'actionnels et mode'lisation. New J Chem. 1998;22(3):263-8. https://doi.org/10.1039/A708335A.

84. Gallard H, De Laat J, Legube B. Spectrophotometric study of the formation of iron(III)-hydroperoxy complexes in homogeneous aqueous solutions. Water Res. 1999;33(13):2929-36. https:/doi. org/10.1016/S0043-1354(99)00007-X.

85. Bottero JY, Tchoubar D, Cases JM, Fiessinger F. Investigation of the hydrolysis of aqueous solutions of aluminum chloride. 2. Nature and structure by small-angle $\mathrm{x}$-ray scattering. J Phys Chem. 1962;86(18):3667-73. https://doi.org/10.1021/j100215a034.
86. Matijevic E, Mathai KG, Ottewill RH, Kerker M. Detection of metal ion hydrolysis by coagulation. III.1 Aluminum2. J Phys Chem. 1961;65(5):826-30. https://doi.org/10.1021/j100823a028.

87. Gray KA, Yao CH, O'Melia CR. Inorganic metal polymers: preparation and characterization. J Am Water Works Assoc. 1995;87(4):136-46.

88. Tang HX, Luan ZK. In: Hahn, H.H., Hoffmann, E., Odegaard, H. (Eds.), Chemical Water and Wastewater Treatment IV, SpringerVerlag; 1996. pp. 83-93.

89. Tang HX, Stumm W. The coagulation behaviors of Fe(III) polymeric species-I. Preformed polymers by base addition. Water Res. 1987;21(1):115-21. https://doi.org/10.1016/0043-1354(87)901060.

90. Tchoubar D, Bottero JY, Quienne P, Arnaud M. Partial hydrolysis of ferric chloride salt. Structural investigation by photon-correlation spectroscopy and small-angle $\mathrm{x}$-ray scattering. Langmuir. 1991;7(2):398-402. https://doi.org/10.1021/la00050a034.

91. Bottero JY, Manceau A, Villieras F, Tchoubar D. Structure and mechanisms of formation of iron oxide hydroxide (chloride) polymers. Langmuir. 1994;10(1):316-9. https://doi.org/10.1021/ la00013a046.

92. Wolfaardt GM, Cloete TE. The effect of some environmental parameters on surface colonization by microorganisms. Water Res. 1992;26(4):527-37. https://doi.org/10.1016/0043-1354(92)900548.

93. Coetser SE, Cloete TE. Biofouling and biocorrosion in industrial water systems. Crit Rev Microbiol. 2005;31(4):213-32. https://doi. org/10.1080/10408410500304074.

94. Flemming H-C. Biofouling in water systems - cases, causes and countermeasures. Appl Microbiol Biot. 2002;59(6):629-40. https:// doi.org/10.1007/s00253-002-1066-9.

95. Yemashova NA, Murygina VP, Zhukov DV, Zakharyantz AA, Gladchenko MA, Appanna V, et al. Biodeterioration of crude oil and oil derived products: a review. Rev Environ Sci Bio. 2007;6(4): 315-37. https://doi.org/10.1007/s11157-006-9118-8.

Publisher's note Springer Nature remains neutral with regard to jurisdictional claims in published maps and institutional affiliations. 